\title{
Individual Cryptomeria fortunei Hooibrenk Clones Show Varying Degrees of Chilling Stress Resistance
}

\author{
Yingting Zhang ${ }^{1,2,3}$, , Qianyu Zhu ${ }^{1,2,3}$, Meng Zhang ${ }^{1,2,3}$, Zhenhao Guo ${ }^{1,2,3}$, Junjie Yang ${ }^{1,2,3}$, \\ Jiaxing Mo ${ }^{1,2,3}$, Jiebing Cui ${ }^{1,2,3}$, Hailiang $\mathrm{Hu}^{1,2,3}$ and Jin $\mathrm{Xu}{ }^{1,2,3, * \mathbb{C}}$ \\ 1 Key Laboratory of Forest Genetics \& Biotechnology of Ministry of Education, Nanjing Forestry University, \\ Nanjing 210037, China; ytzhang@njfu.edu.cn (Y.Z.); 302603143.1@163.com (Q.Z.); \\ 17805151500@163.com (M.Z.); 18915019168@163.com (Z.G.); 18260077751@163.com (J.Y.); \\ jx_mo@njfu.edu.cn (J.M.); cuijiebing@163.com (J.C.); hhl1198264682@163.com (H.H.) \\ 2 Co-Innovation Center for Sustainable Forestry in Southern China, Nanjing Forestry University, \\ Nanjing 210037, China \\ 3 College of Forestry, Nanjing Forestry University, Nanjing 210037, China \\ * Correspondence: xjinhsh@njfu.edu.cn; Tel.: +86-25-8542-7319
}

Received: 7 January 2020; Accepted: 5 February 2020; Published: 7 February 2020

\begin{abstract}
Low temperature (LT) is an important abiotic factor affecting plant survival, growth and distribution. The response of Cryptomeria fortunei (Chinese cedar) to LT is not well known, limiting its application in production and ornamental value. In this study, we first screened ten clones (\#3, \#25, \#32, $\# 42$, \#54, \#57, \#68, \#66, \#74, \#X1), originating from five different locations in China, for their degrees of cold resistance. We then selected the two showing the highest (\#32) and lowest (\#42) cold resistance to see the physiological and morphological response of different cold-resistant $C$. fortunei clones to LT. We found that the electrolyte leakage of all ten clones increased strongly between 0 and $-8^{\circ} \mathrm{C}$, while below -8 or between 4 and $0{ }^{\circ} \mathrm{C}$ did not yield additional increases. Under cold stress, clones \#32 and \#42 showed different degrees of needle browning. From 25 to $-20^{\circ} \mathrm{C}$, maximum and effective quantum yields of photosystem II ( $F_{\mathrm{v}} / F_{\mathrm{m}}$ and YII) and photochemical and non-photochemical quenching ( $\mathrm{qP}$ and NPQ) decreased continuously in two clones with decreasing temperature, where \#42 was more strongly affected compared with \#32. The chlorophyll content first decreased significantly to the lowest from 25 to $-12{ }^{\circ} \mathrm{C}$, then increased significantly at $-16 /-20^{\circ} \mathrm{C}$ compared with $-12{ }^{\circ} \mathrm{C}$. We observed changes in needle cellular ultrastructure at $-8^{\circ} \mathrm{C}$, with chloroplasts of \#32 swelling, while those of \#42 were destroyed. Correlation analysis indicated that needle browning and chlorophyll fluorescence were closely related to temperature, and cellular ultrastructure changed notably around semi-lethal temperature $\left(\mathrm{LT}_{50}\right)$, which can be used as physiological indicators for the identification of cold resistance. We found a clear difference in cold tolerance between clones of \#32 and \#42, with \#32 being more tolerant, which can be exploited in breeding programs. We conclude that strongly cold-resistant clones have more stable physiological states and a wider adaptability to LT compared with weak ones.
\end{abstract}

Keywords: low-temperature stress; needle phenotype; chlorophyll content; chlorophyll fluorescence; plant cell ultrastructure

\section{Introduction}

Low temperature (LT) is one of the most important abiotic stress factors affecting plant survival and growth, and it is also the main factor that determines the geographical distribution and growth season of plants [1]. Cold resistance is a complex feature and can be a major influence on plant survival [2]. During their life cycles, most terrestrial plants that are grown in temperate or cold regions are affected 
by LT, which usually is defined as cold stress (above $0{ }^{\circ} \mathrm{C}$ ) or freezing stress (below $0{ }^{\circ} \mathrm{C}$ ) [3]. Freezing stress usually leads to the formation of intracellular ice crystals, as well as mechanical dehydration, which will cause an increase of intracellular salt concentration, irreversible damage to plant cells and metabolic defects $[4,5]$. Therefore, frost-resistant plants are assumed to have specific cellular structures and intracellular components that are able to withstand the mechanical and osmotic stresses caused by freezing.

Plants display physiological changes under cold stress [6]. Previous studies have shown that cold treatment on LT-sensitive plants accelerates their electrolyte flow and increases permeability of cellular membranes, leading to serious membrane damage and "membrane leakage" phenomena [7]. The intracellular concentration of ions and organic substances can be used to measure electrolyte leakage (EL) levels [8,9]; EL levels and the semi-lethal temperature $\left(\mathrm{LT}_{50}\right)$ caused by freezing stress have been widely used for the diagnosis of cold resistance [10-12]. Plant photosynthesis is sensitive to temperature. The most obvious changes in response to cold stress occur in photosynthetic components, pigment complexes, photosynthetic rates and chloroplast structures [13,14]. Chlorophyll is a photosynthetic pigment used as an index of leaf photosynthetic capacity [15-17]. Freezing stress reduces plant metabolism and affects the biosynthesis of photosynthetic pigments, significantly decreasing chlorophyll content [18] as well as photosynthetic capacity. Chlorophyll fluorescence provides information on energy capture and electron transport in photosynthesis, and it also reflects the intrinsic characteristics of the photosynthetic systems [19], so it is widely used to study the effects of stress factors on plant photosynthesis [20,21]. Maximum quantum yield of photosystem II (PSII) $\left(F_{\mathrm{v}} / F_{\mathrm{m}}\right)$, which reflects maximum PSII efficiency and is regarded as an indicator of plant PSII damage [22-24], reduces under cold stress and is commonly used to evaluate each photosynthetic capacity under various environmental stresses. Plants also display cellular changes under cold stress [12]. Chloroplasts are the most sensitive plant organelles and display the earliest visible damages in plant cell under stress [25]. Irreversible hypothermia damage first occurs on the plasma membrane [26] and destroys its structure [27]. Ultrastructural changes are generally similar among species at LT, including swelling deformation of chloroplasts and mitochondria, expansion of thylakoids, reduction in size and quantity of starch grains in the chloroplasts and so forth [28].

Cryptomeria fortunei Hooibrenk is an evergreen conifer species of Taxodiaceae. It is an endemic species to southern China and is widely distributed from the south of the Yangtze River (Zhejiang, Fujian, etc.) to the provinces of Guangdong, Guangxi, Yunnan, Guizhou, Sichuan and so forth. It is an important plant species in wood production, carbon storage and ecological restoration [29]. To date, research on C. fortunei has mainly focused on forest cultivation [30] and analysis of its chemical composition [31]. Needle discoloration is the most prominent sign of freezing injury [32], and it affects plant growth [33]. The greater the area and darker the color of leaf browning, the greater the degree of frost damage and the weaker the cold resistance [34]. In Nanjing, needles of C. fortunei seedlings will turn yellow and reddish brown in winter. Some of them will return to green in springtime if under mild low-temperature stress (LTS) (other brown needles shed); otherwise, under severe LT, needles will turn browner and shed more, and even the whole plant may die. Although C. fortunei can cope with moderate LT [35], not much is known about how it adapts to cold stress. To gain insight into whether and how $C$. fortunei resists cold stress, we preselected the strongest and weakest cold-resistant clones among 10 tested clones. Then we analyzed the changes of needle phenotype, chlorophyll fluorescence parameters, chlorophyll content and ultrastructure of these two clones under LT conditions. Our work provides a basis for molecular breeding of cold-resistant $C$. fortunei.

\section{Materials and Methods}

\subsection{Plant Material}

We acquired C. fortunei from its distribution area in eastern China, listed in Table 1. In June 2014, healthy, uniform and semi-lignified cuttings were collected from 10 trees, respectively (the cuttings in 
each tree are called a clone). After soaking in deionized water for $12 \mathrm{~h}$, the cuttings (approximately 10-12 cm) were surface-sterilized in 1\% sodium hypochlorite for $10 \mathrm{~min}$ and then rinsed three times with distilled water. Afterwards, the cuttings were soaked in $0.1 \mathrm{~g} \cdot \mathrm{L}^{-1}$ Two-Gill (GGR) 6 rooting powder solution for $4 \mathrm{~h}$, then were grown in black plastic pots ( $35 \mathrm{~cm}$ in diameter and $35 \mathrm{~cm} \mathrm{height)}$ filled with a sterilized mixture of vermiculite, perlite and yellow sand $(1: 2: 2, \mathrm{v}: \mathrm{v}: \mathrm{v})$ and cultivated at Baima teaching and research base of Nanjing Forestry University ( $\left.31^{\circ} 37^{\prime} \mathrm{N}, 119^{\circ} 11^{\prime} \mathrm{E}\right)$, Nanjing City, Jiangsu Province, China. These plastic pots were placed in cutting pools under natural temperature and light conditions (except for $40 \%$ shading in summer). Plants were water-sprayed (once every three days in summer, and once a week in other seasons) regularly. They were weeded three times every year (in April, July and October) followed by fertilization with $10 \mathrm{~g}$ compound granular fertilizer for each plant every time.

Table 1. The geographic location of $C$. fortunei materials.

\begin{tabular}{|c|c|c|c|c|c|c|c|}
\hline Clones & Sources & $\begin{array}{l}\text { Longitude } \\
\text { (E) }\end{array}$ & $\begin{array}{l}\text { Latitude } \\
\text { (N) }\end{array}$ & $\begin{array}{l}\text { Altitude } \\
\text { (m) }\end{array}$ & Aspect & $\begin{array}{c}\text { Average } \\
\text { Annual } \\
\text { Temperature } \\
\left({ }^{\circ} \mathrm{C}\right)\end{array}$ & $\begin{array}{l}\text { Average } \\
\text { Annual } \\
\text { Precipitation } \\
\text { (mm) }\end{array}$ \\
\hline$\# 42$ & $\begin{array}{l}\text { Shiyang Forest Farm, } \\
\text { Wencheng County, } \\
\text { Zhejiang Province }\end{array}$ & $119^{\circ} 50^{\prime}$ & $27^{\circ} 50^{\prime}$ & $890-980$ & north & 12.4 & 1910 \\
\hline $\begin{array}{c}\# 54, \# 57, \# 68, \\
\# 66, \# 74\end{array}$ & $\begin{array}{l}\text { State--owned Forest } \\
\text { Farm of Xiapu, Xiapu } \\
\text { County, Fujian Province }\end{array}$ & $119^{\circ} 57^{\prime}$ & $26^{\circ} 52^{\prime}$ & 100 & southeast & 18.5 & $1400-1600$ \\
\hline
\end{tabular}

\subsection{LT Treatment}

In June 2019, one-year semi-lignified branches with no visible damage from 10 clones of $C$. fortunei (5-year-old cuttage seedlings, at heights of 100-120 cm) were collected and transferred to our laboratory in Nanjing $\left(118^{\circ} 50^{\prime} \mathrm{E}, 32^{\circ} 05^{\prime} \mathrm{N}\right)$ at ambient temperature in the dark, a process that took around $2-3 \mathrm{~h}$. Branches were rinsed with deionized water and surface-dried with clean filter papers. Material from each clone was divided into 8 groups for different treatments. Each treatment was performed in triplicate $(10 \times 3$ branches $)$ and packed in a $0.03 \mathrm{~mm}$ thick polyvinyl chloride (PVC) storage bag. One group, placed in the dark at room temperature $\left(25^{\circ} \mathrm{C}\right)$, served as control $(\mathrm{CK})$, the other groups were placed in a program-controlled refrigerator (BCD-405WDGQU1, Haier, Qingdao, Shandong Province, China) for LT treatment $\left(4,0,-4,-8,-12,-16\right.$ and $\left.-20{ }^{\circ} \mathrm{C}\right)$ for $12 \mathrm{~h}$. The temperature was decreased at a rate of $4{ }^{\circ} \mathrm{C} / \mathrm{h}$, starting from $4{ }^{\circ} \mathrm{C}$ down to the aimed temperature [36]. After $12 \mathrm{~h}$ treatment, samples above $0{ }^{\circ} \mathrm{C}\left(25\right.$ and $\left.4{ }^{\circ} \mathrm{C}\right)$ could be directly used for the measurement of physiological indexes, whereas samples treated at and below $0{ }^{\circ} \mathrm{C}$ were raised to $4{ }^{\circ} \mathrm{C}$ at a rate of 4 ${ }^{\circ} \mathrm{C} / \mathrm{h}$, then the physiological indexes were analyzed. The same treatments were used for \#32 and \#42 clones for different time points (2 and $24 \mathrm{~h})$.

\subsection{Electrolyte Leakage (EL) and Semi-Lethal Temperature $\left(L T_{50}\right)$}

EL was measured according to the method of Tsarouhas et al. [37] and Ma et al. [38] with some modifications. Briefly, the needles of LT-treated samples were collected and incubated in $20 \mathrm{~mL}$ of distilled water at room temperature. After $12 \mathrm{~h}$ incubation, $0.2 \mathrm{~g}$ of needles was used, and its conductivity was measured as $\mathrm{E}_{1}$ with a conductivity meter (DDS-307, Leici Instruments Co., Shanghai, China), setting the conductivity of distilled water as $\mathrm{E}_{0}$. The samples were boiled for 20 min. After 
cooling to room temperature, the ultimate conductivity was measured as $\mathrm{E}_{2}$. EL was calculated using the following formula:

$$
\mathrm{EL}(\%)=\left(\mathrm{E}_{1}-\mathrm{E}_{0}\right) /\left(\mathrm{E}_{2}-\mathrm{E}_{0}\right) \times 100,
$$

A series of EL was combined with the exponential equation $y=k /\left(1+a e^{-b t}\right)$ to obtain intermediate parameters for the plant $\mathrm{LT}_{50}$. Within this formula, $\mathrm{y}$ is $\mathrm{EL}, \mathrm{k}$ is the maximum $\mathrm{EL}, \mathrm{t}$ is temperature, e (about 2.718) is constant, and $a$ and $b$ are values calculated by the equation. Let $Y=\ln (k-y) / y$, the equation is transformed to $Y=\ln a-b x$, then $x=(\ln a) / b$ and $x$ is the $\operatorname{LT}_{50}[39,40]$.

\subsection{Needle Phenotype Observations}

Fifteen branches of \#32 and \#42 clones were treated in the same way as above for 2, 12 and $24 \mathrm{~h}$, respectively, and then placed in a $4^{\circ} \mathrm{C}$ refrigerator (BCD-405WDGQU1, Haier, Qingdao, Shandong Province, China) for $12 \mathrm{~h}$. Branches placed at $25{ }^{\circ} \mathrm{C}$ were used as controls $(\mathrm{CK})$. The needles were phenotyped. The browning degrees were classified according to the depth and areas of browning, then the browning index was calculated [39]. The browning degrees were divided into 5 grades: grade 1, nonbrowning, green; grade 2 , slight browning, $0-1 / 4$ area of browning on the surface; grade $3,1 / 4-1 / 2$ area of browning on the surface; grade $4,1 / 2-3 / 4$ area of browning on the surface; grade 5 , greater than $3 / 4$ area of browning on the surface, dark brown. The browning index was calculated by browning grade and browning area, and the equation was

$$
\text { Browning index }(\%)=\frac{\sum(\text { each browning grade } \times \text { percentage of browning area of each grade })}{(\text { the highest grade of browning } \times \text { total number of branches })} \times 100,
$$

\subsection{Chlorophyll Content}

The needles of \#32 and \#42 clones were collected after LT treatment as described above for 2, 12 and $24 \mathrm{~h}$. Chlorophyll content was measured using the alcohol extraction method described by Lichtenthaler and Wellburn [41]. The chlorophyll was extracted by grinding each sample (about $0.1 \mathrm{~g}$ ) with calcium carbonate, quartz sand and $96 \%$ alcohol and then incubating for several minutes until tissues were blanched. After centrifuging (Allegra X-22R, Beckman Coulter, Inc, Breabbe, California, USA) 3 times at $4000 \mathrm{rpm}$ for $20 \mathrm{~min}$ each time at room temperature, the $\mathrm{OD}_{665}$ (optical density at $665 \mathrm{~nm}$ ) and $\mathrm{OD}_{649}$ (optical density at $649 \mathrm{~nm}$ ) of the supernatant were determined using a spectrophotometer (V-1200, Shanghai Mapada Instruments Co., Ltd., Shanghai, China). The concentration of chlorophyll (mg g $\mathrm{g}^{-1}$ fresh weight) was calculated using Lichtenthaler and Wellburn equations [41].

\subsection{Chlorophyll Fluorescence Characteristics}

The needles of \#32 and \#42 clones were collected after LT treatment as described above for 2, 12 and $24 \mathrm{~h}$, then the chlorophyll fluorescence transient was determined using a fluorimeter (Dual-PAM/F-100, Walz, Effeltrich, Baden-Wuertenberg, Germany) [42]. The third to the fifth mature needles from top to bottom were placed in the dark for $30 \mathrm{~min}$ before measurements. A saturating light $\left(3500 \mu \mathrm{mol} \mathrm{m}^{-2} \mathrm{~s}^{-1}\right)$ along with actinic light $\left(300 \mu \mathrm{mol} \mathrm{m} \mathrm{m}^{-2} \mathrm{~s}^{-1}\right)$ was applied, and the dual-channel mode (fluo + P700) was adopted to measure the induction curve. The fluorescence signal was stable for 5 min under photochemical conditions, and the following fluorescence parameters were measured as indicators of the functionality of the photosynthetic apparatus: initial fluorescence $\left(F_{\mathrm{o}}\right)$, maximum fluorescence $\left(F_{\mathrm{m}}\right)$, $F_{\mathrm{v}} / F_{\mathrm{m}}$ (variable fluorescence $F_{\mathrm{v}}=F_{\mathrm{m}}-F_{\mathrm{o}}$ ), the effective quantum yield of PSII (YII), photochemical quenching (qP) and non-photochemical quenching (NPQ).

\subsection{Ultrastructural Observations}

Branches of \#32 and \#42 treated at $-4,-8$ and $-20{ }^{\circ} \mathrm{C}$ for $24 \mathrm{~h}$ were collected, and samples at $25^{\circ} \mathrm{C}$ were used as a control (CK). For each treatment, three needles (the third to the fifth mature needles from top to bottom) were sampled and fixed in $3 \%$ glutaraldehyde solution in phosphate buffer with 
a $\mathrm{pH}$ of 7.0 for $24 \mathrm{~h}$ at room temperature, followed by secondary fixation in $2.5 \%$ osmium tetroxide solution for $2 \mathrm{~h}$. The specimens were rinsed and dehydrated in a graded series of alcohols and acetone of increasing strength until $100 \%$ and embedded in turn in a gradient of absolute ethanol and Poly Bed 812 epoxy resin $(3: 1,1: 1,1: 3,0: 3)$. The samples were stored dry for $8 \mathrm{~h}$. Ultrathin sections $(80-100 \mathrm{~nm})$ were obtained using an ultratome III ultramicrotome (LKB, Bromma, Stockholm Province, Sweden) and observed using transmission electron microscopy (TEM) (JEM-2100, JEOL Ltd., Tokyo, Japan) after being stained in uranyl acetate and lead citrate [43]. From the electronic microscope images, 10 chloroplasts were selected for observation and measurement. The chloroplasts were approximated as ellipses, then the lengths of the semi major and semi minor axes of the ellipse were measured, respectively, and the approximate areas of the transverse sections of the chloroplasts in mesophyll cells were calculated. The elliptical area was calculated by the following equation:

$$
\mathrm{S}=\pi \mathrm{ab},
$$

where $S$ is the elliptical area $\left(\mu \mathrm{m}^{2}\right) ; \pi$ is pi; and a and b are the length of semi major axis $(\mu \mathrm{m})$ and semi minor axis $(\mu \mathrm{m})$, respectively.

\subsection{Statistical Analysis}

The experimental data were first collected, then statistically analyzed and plotted using Excel 2003 (Microsoft Co., Redmond, Washington, USA). All data shown in this study are mean values and standard errors (SEs). The data checked for the normal distribution ( $p-p$ chart) were statistically analyzed using one-way analysis (temperature as a factor) of variance in SPSS v25.0 (SPSS, Inc, an IBM Co., Chicago, Illinois, USA), and Duncan's multiple range test at a confidence level of $95 \%(p<0.05)$ was adopted to define the statistical significance of the difference [44].

\section{Results}

\subsection{Individual C. fortunei Clones Show Varying Degrees of Cold Resistance}

We aimed to preselect the most and least cold resistant out of $10 \mathrm{C}$. fortunei clones (isolated from 5 places in China) by analyzing their electrolyte leakage (EL) and semilethal temperature (LT 50$)$ values in response to cold stress. As temperature decreased, all clones showed a similar S-curve response of increasing EL values (Figure 1). The EL of needles of most C. fortunei clones increased slowly from 4 to $0{ }^{\circ} \mathrm{C}$, and only $\# 42$ significantly increased by $121.05 \%$. Whereas, the EL of each clone rapidly increased between 0 and $-8{ }^{\circ} \mathrm{C}$ to $61 \%-73 \%$. Any further reduction in temperature below $-8{ }^{\circ} \mathrm{C}$ did not yield additional increase in EL values (Figure 1). We used an exponential equation to derive a response curve function for each of the clones, which gave a significant fitting degree $\left(R^{2}\right)$ in all cases (Table 2). From these curve functions we could derive that clone \#32 showed the lowest $\mathrm{LT}_{50}\left(-7.8^{\circ} \mathrm{C}\right)$, while \#42 showed the highest $\left(-4.7^{\circ} \mathrm{C}\right.$ ) (Table 2$)$. We then selected these two clones for further experiments in order to study the widest possible range of cold-resistant responses within C. fortunei [45-47].

Table 2. Regression equation of electrolyte leakage and temperature and semi-lethal temperature of C. fortunei.

\begin{tabular}{cccc}
\hline Clones & Regression Equation & Fitting Degree $\left(\boldsymbol{R}^{\mathbf{2}}\right)$ & Semi-Lethal Temperature $\left({ }^{\circ} \mathbf{C}\right)$ \\
\hline$\# 3$ & $\mathrm{y}=0.1246 \mathrm{x}+0.8394$ & 0.7979 & -6.7 \\
$\# 25$ & $\mathrm{y}=0.1261 \mathrm{x}+0.7907$ & 0.8288 & -6.3 \\
$\# 32$ & $\mathrm{y}=0.1232 \mathrm{x}+0.9614$ & 0.9054 & -7.8 \\
$\# 42$ & $\mathrm{y}=0.089 \mathrm{x}+0.4225$ & 0.7577 & -4.7 \\
$\# 54$ & $\mathrm{y}=0.1173 \mathrm{x}+0.7212$ & 0.8002 & -6.1 \\
$\# 57$ & $\mathrm{y}=0.1260 \mathrm{x}+0.9076$ & 0.8506 & -7.2 \\
$\# 66$ & $\mathrm{y}=0.1200 \mathrm{x}+0.7860$ & 0.8130 & -6.5 \\
$\# 68$ & $\mathrm{y}=0.1156 \mathrm{x}+0.7518$ & 0.8323 & -6.6 \\
$\# 74$ & $\mathrm{y}=0.1284 \mathrm{x}+0.7873$ & 0.9283 & -6.1 \\
$\#$ \#1 & $\mathrm{y}=0.1104 \mathrm{x}+0.6623$ & 0.8166 & -6.0 \\
\hline
\end{tabular}




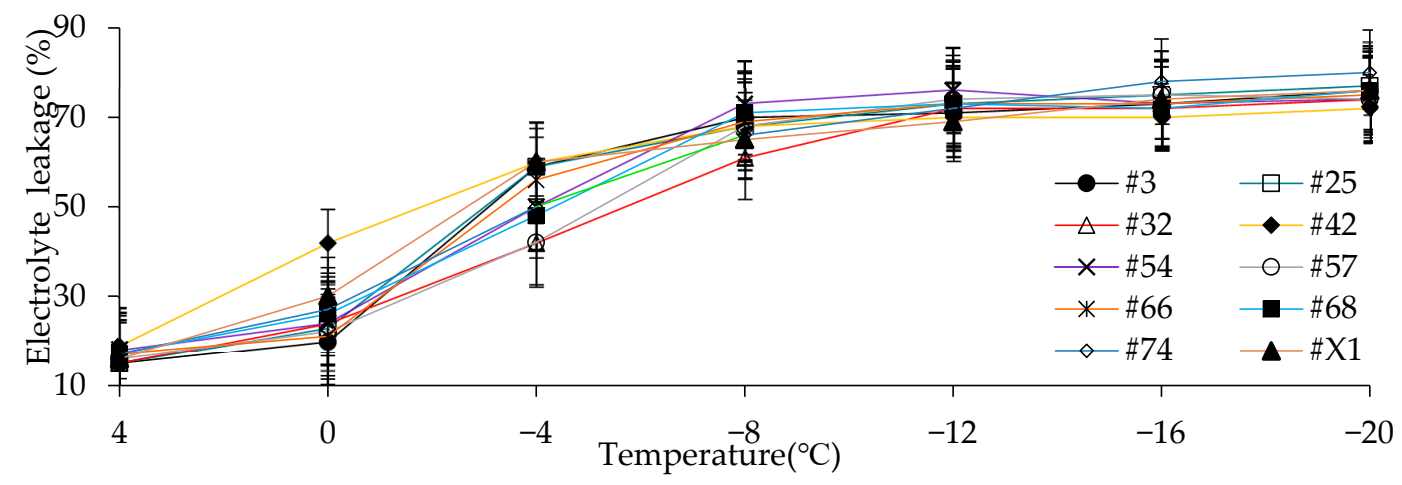

a
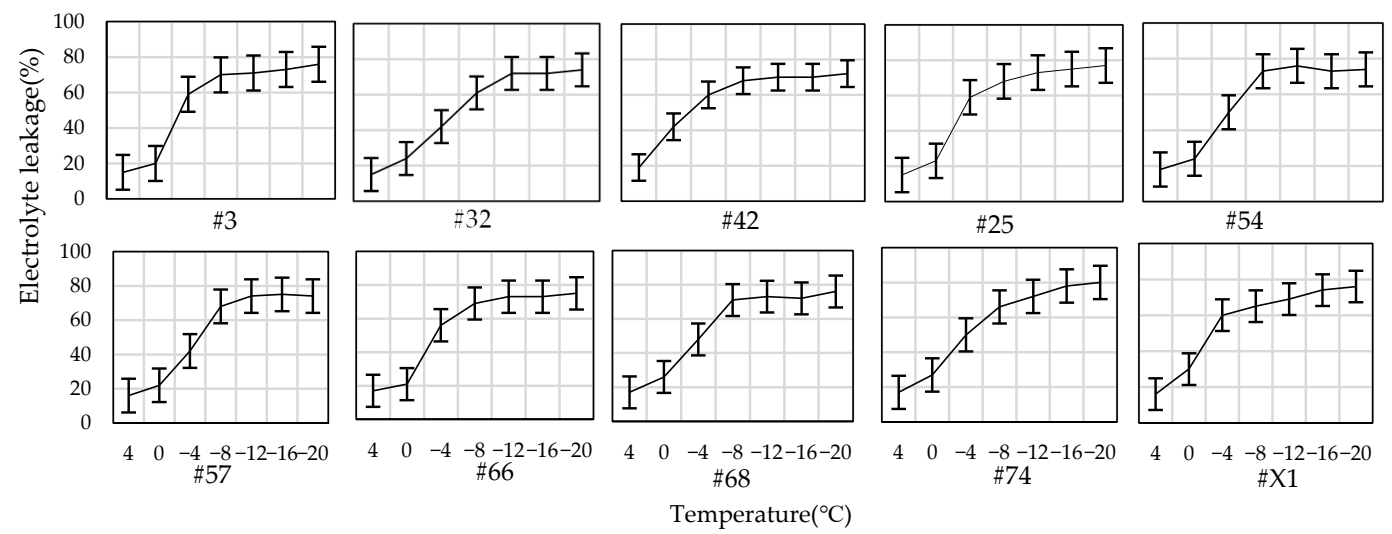

b

Figure 1. (a) Variations of electrolyte leakage of 10 C. fortunei clones under low-temperature stress.

(b) The electrolyte leakage of each clone. Displayed is the average \pm the standard error, $n=6$.

\subsection{Low-Temperature Stress (LTS) Causes Needle Damage in C. fortunei Clones}

Cold acclimation often leads to changes in leaf color and shape $[48,49]$. To test how and whether needle phenotypes related to cold resistance, we calculated the browning indexes of needles of clones $\# 32$ and \#42 under LTS at a series of decreasing temperatures. After $2 \mathrm{~h}$ LT treatment, needles of both \#32 and \#42 did not show significant differences in both needle shape and color at temperatures $\geq-4{ }^{\circ} \mathrm{C}$, compared to the control $\left(25^{\circ} \mathrm{C}\right)$, yet at $\leq-8{ }^{\circ} \mathrm{C}$ they showed varying degrees of chlorosis (Figure 2a,b, Table 3). After treating for 12 or $24 \mathrm{~h}$, only needles kept at $\geq 0{ }^{\circ} \mathrm{C}$ showed no obvious changes in needle color, while chlorosis started to appear at $\leq-4{ }^{\circ} \mathrm{C}$ (Table 3). Furthermore, this prolonged treatment below $-12{ }^{\circ} \mathrm{C}$ also caused top needles to wilt and droop, making them thicker and easier to detach (Figure 2c-f). With a decrease in temperature and prolongation of LT treatment, the degree of browning damage increased significantly compared with the control (Figure 2, Table 3). In addition, any phenotypic changes in response to cold stress were less obvious in clones \#32 than in \#42, consistent with the fact that \#32 showed a lower $\mathrm{LT}_{50}$ than that of \#42 (Table 2). 
\#32
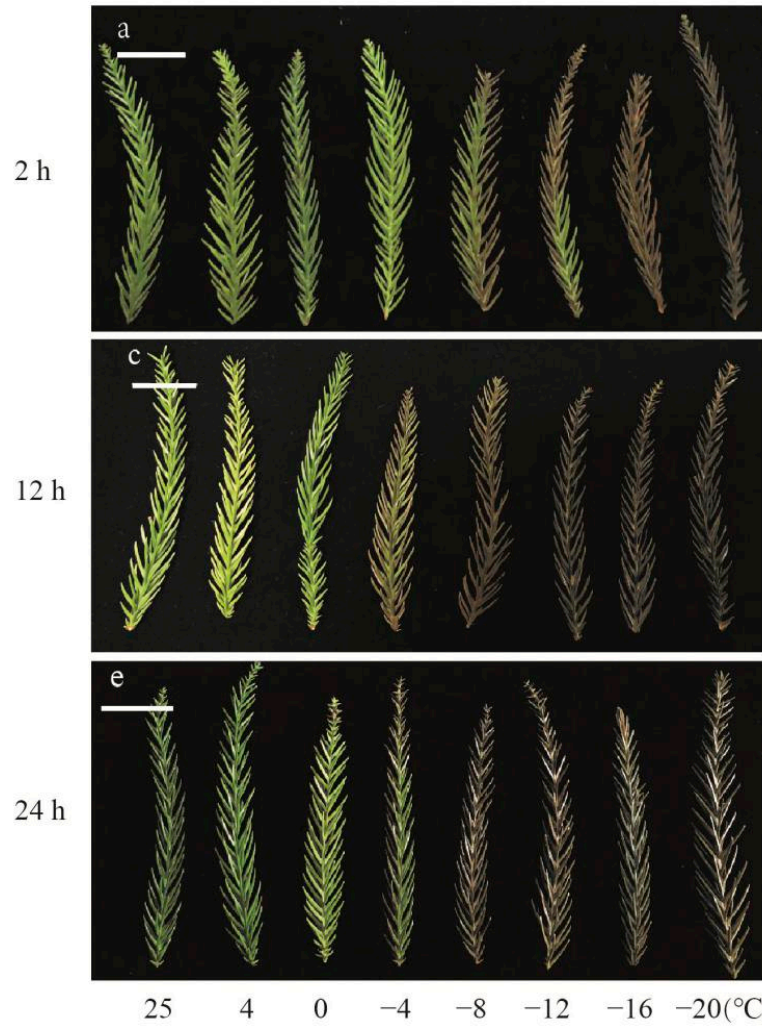

$\# 42$
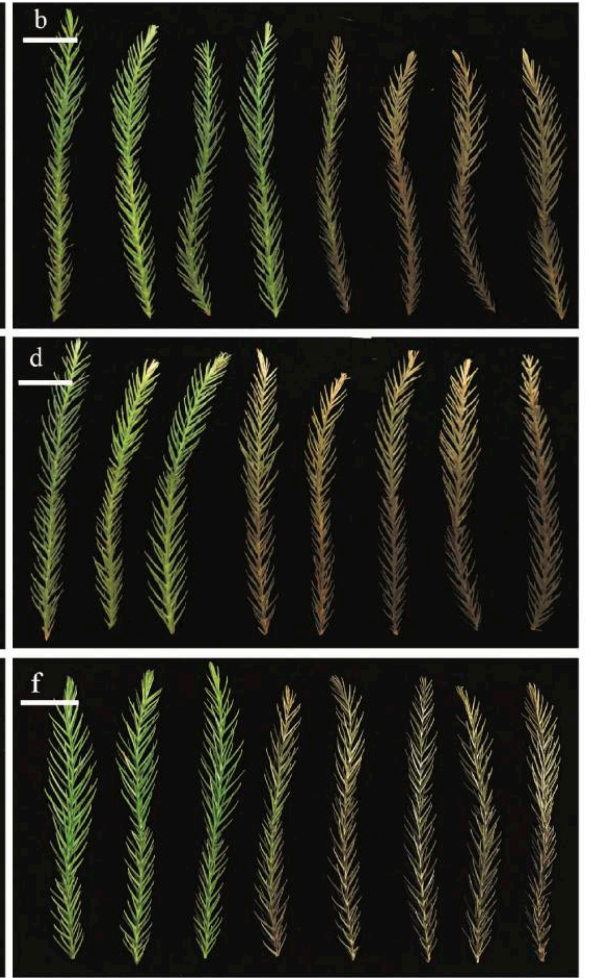

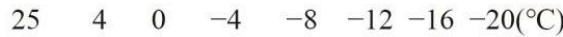

Figure 2. The needle phenotype of the $C$. fortunei clones changed significantly under different low-temperature stress (LTS). (a) Needle phenotype of \#32 under 2 h LTS; (b) needle phenotype of \#42 under 2 h LTS; (c) needle phenotype of \#32 under 12 h LTS; (d) needle phenotype of \#42 under 12 h LTS; (e) needle phenotype of \#32 under $24 \mathrm{~h}$ LTS; (f) needle phenotype of \#42 under $24 \mathrm{~h}$ LTS. Bars $=3 \mathrm{~cm}$.

Table 3. Browning index of $C$. fortunei clones under low-temperature stress.

\begin{tabular}{ccccccc}
\hline & \multicolumn{7}{c}{ Browning Index } \\
\cline { 2 - 7 } Temperature $\left({ }^{\circ} \mathbf{C}\right)$ & \multicolumn{7}{c}{ \#32 } & $\mathbf{2 4 ~ h} \mathbf{~ h}$ & $\mathbf{1 2 ~ h}$ & $\mathbf{2 4} \mathbf{h}$ \\
\cline { 2 - 7 } & $0 \pm 0 \mathrm{e}$ & $0 \pm 0 \mathrm{f}$ & $0 \pm 0 \mathrm{f}$ & $0 \pm 0 \mathrm{e}$ & $0 \pm 0 \mathrm{e}$ & $0 \pm 0 \mathrm{f}$ \\
\hline 25 & $0 \pm 0 \mathrm{e}$ & $0 \pm 0 \mathrm{f}$ & $0 \pm 0 \mathrm{f}$ & $0 \pm 0 \mathrm{e}$ & $0 \pm 0 \mathrm{e}$ & $0 \pm 0 \mathrm{f}$ \\
4 & $0 \pm 0 \mathrm{e}$ & $0 \pm 0 \mathrm{f}$ & $0 \pm 0 \mathrm{f}$ & $0 \pm 0 \mathrm{e}$ & $0 \pm 0 \mathrm{e}$ & $0 \pm 0 \mathrm{f}$ \\
0 & $0 \pm 0 \mathrm{e}$ & $0.32 \pm 0.021 \mathrm{e}$ & $0.36 \pm 0.010 \mathrm{e}$ & $0 \pm 0 \mathrm{e}$ & $0.34 \pm 0.010 \mathrm{~d}$ & $0.37 \pm 0.015 \mathrm{e}$ \\
-4 & $0.19 \pm 0.025 \mathrm{~d}$ & $0.51 \pm 0.021 \mathrm{~d}$ & $0.68 \pm 0.021 \mathrm{~d}$ & $0.23 \pm 0.010 \mathrm{~d}$ & $0.67 \pm 0.026 \mathrm{c}$ & $0.76 \pm 0.010 \mathrm{~d}$ \\
-8 & $0.31 \pm 0.021 \mathrm{c}$ & $0.62 \pm 0.012 \mathrm{c}$ & $0.75 \pm 0.015 \mathrm{c}$ & $0.54 \pm 0.021 \mathrm{c}$ & $0.74 \pm 0.026 \mathrm{~b}$ & $0.84 \pm 0.021 \mathrm{c}$ \\
-12 & $0.54 \pm 0.015 \mathrm{~b}$ & $0.77 \pm 0.031 \mathrm{~b}$ & $0.87 \pm 0.026 \mathrm{~b}$ & $0.69 \pm 0.021 \mathrm{~b}$ & $0.82 \pm 0.017 \mathrm{a}$ & $0.93 \pm 0.020 \mathrm{~b}$ \\
-16 & $0.79 \pm 0.023 \mathrm{a}$ & $0.85 \pm 0.015 \mathrm{a}$ & $0.94 \pm 0.031 \mathrm{a}$ & $0.79 \pm 0.020 \mathrm{a}$ & $0.86 \pm 0.015 \mathrm{a}$ & $0.98 \pm 0.007 \mathrm{a}$ \\
\hline-20 & &
\end{tabular}

For every treatment, 15 branches $(5 \times 3, n=3)$ were measured, and each value is the mean of 15 branches. Values are mean \pm standard error, lowercase letters in the same column indicate significant differences $(p<0.05)$.

\subsection{Chlorophyll Contents of the C. fortunei Clones Change under Different LTS}

Since we found that increasing LTS caused a greater degree of needle browning in C. fortunei, we sought to determine whether the chlorosis we observed was related to a decrease in chlorophyll content and low cold resistance. We found that with decreasing temperature, chlorophyll $\mathrm{a}, \mathrm{b}$ and $\mathrm{a}+$ b content of \#32 and \#42 needles would initially decline steadily from 25 to $-12{ }^{\circ} \mathrm{C}(p<0.05)$, only to rise again at -16 and/or $-20^{\circ} \mathrm{C}$ (Figure 3). With the prolongation of LT treatment time $(2,12,24 \mathrm{~h}$ ), the chlorophyll content of clone \#32 was rather stable, while that of \#42 needles decreased further (Figure 3). Chlorophyll $\mathrm{a}, \mathrm{b}$ and $\mathrm{a}+\mathrm{b}$ content of clone \#42 needles decreased significantly faster than those of clone \#32. These results suggest that the variations of clone \#32 were smaller and the change 
processes were slower at LT for no more than $24 \mathrm{~h}$, indicating that clone \#32 was more stable to cold stress than clone \#42.
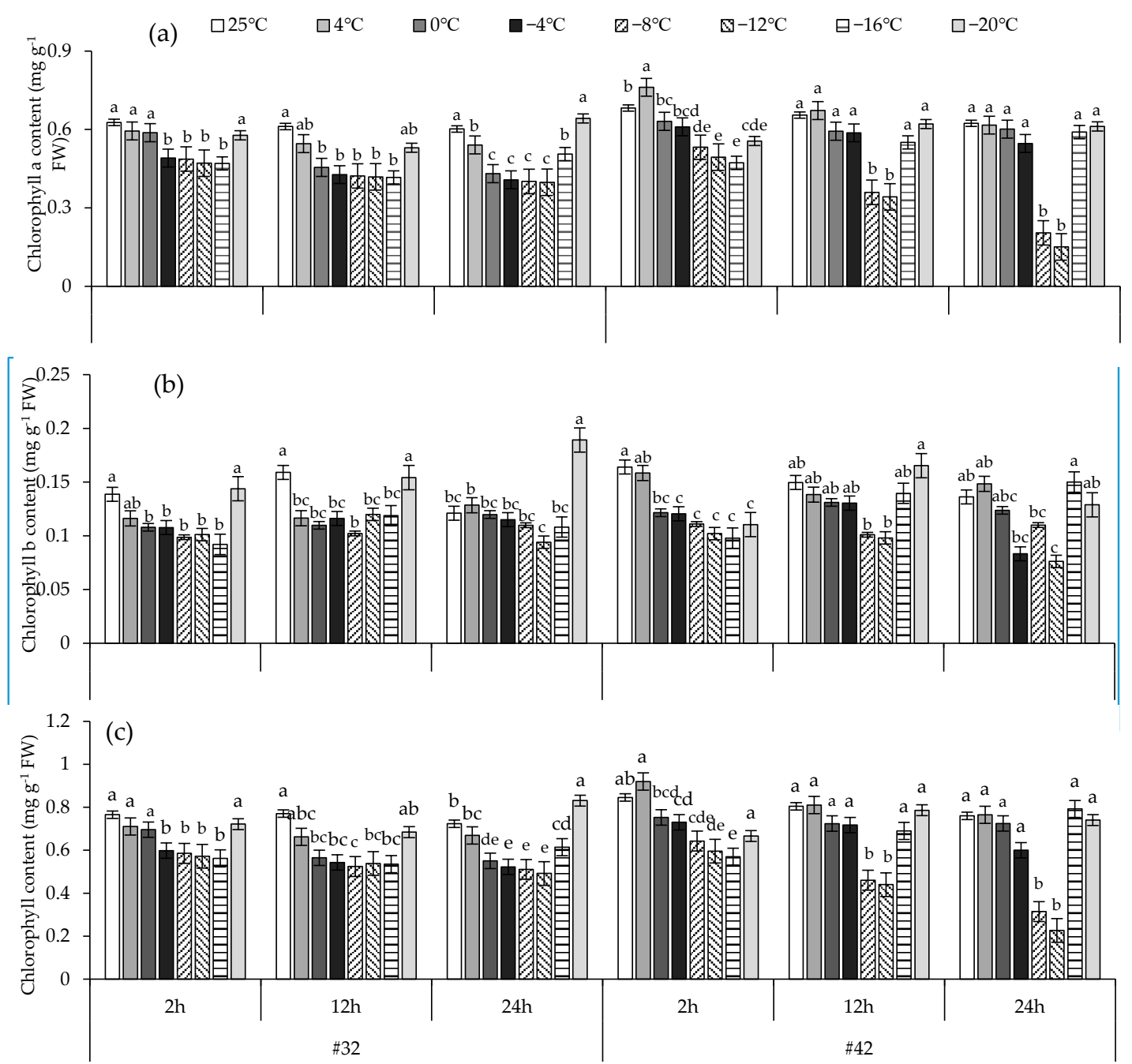

Figure 3. Chlorophyll changes of $C$. fortunei clones under different low-temperature stress. (a) Chlorophyll a content; (b) chlorophyll b content; (c) chlorophyll $\mathrm{a}+\mathrm{b}$ content. Each value in the graph is the mean \pm standard error $(n=6)$. Different patterns indicate different treatment temperatures, and lowercase letters above each bar indicate significant differences $(p<0.05)$.

\subsection{Chlorophyll Fluorescence of C. fortunei is Negatively Affected by LT}

We next tested whether the needle browning we observed in $C$. fortunei clones under cold stress indeed resulted in lowered chlorophyll fluorescence by analyzing their $F_{\mathrm{v}} / F_{\mathrm{m}}, \mathrm{YII}, \mathrm{qP}$ and NPQ in detail. We found that $F_{\mathrm{v}} / F_{\mathrm{m}}$ ratios of \#32 and \#42 needles were reduced with a decrease in temperature and prolongation of LTS time (Figure $4 \mathrm{a}$ ). For clone $\# 32$, the $F_{\mathrm{v}} / F_{\mathrm{m}}$ of the needles decreased rapidly below $-12{ }^{\circ} \mathrm{C}$ when treating for $2 \mathrm{~h}$ or between -8 and $-20{ }^{\circ} \mathrm{C}$ when treating for 12 or $24 \mathrm{~h}$. For clone $\# 42$, under cold treatment for $2 \mathrm{~h}, F_{\mathrm{v}} / F_{\mathrm{m}}$ of the needles decreased sharply between -8 and $-12{ }^{\circ} \mathrm{C}$, while at 12 and $24 \mathrm{~h}$ treatment times, this effect was seen between -4 and $-8^{\circ} \mathrm{C}$ (Figure $4 \mathrm{a}$ ). The $F_{\mathrm{v}} / F_{\mathrm{m}}$ value of clone $\# 32$ at $-20{ }^{\circ} \mathrm{C}$ was similar to or higher than that of clone $\# 42$ at $-12{ }^{\circ} \mathrm{C}$. The trends of YII, $\mathrm{qP}$ and NPQ were almost the same as that of $F_{\mathrm{v}} / F_{\mathrm{m}}$, showing a stable trend (from 25 to $-4{ }^{\circ} \mathrm{C}$ ), then rapid decline (from -4 to $-8 /-12 /-16^{\circ} \mathrm{C}$ ) and finally a stable trend. For temperatures between -4 and $-8 /-12^{\circ} \mathrm{C}$, the decreasing range of \#32 was less than that of \#42 and the value of \#32 was higher than that of \#42 (Figure $4 \mathrm{~b}-\mathrm{d})$. YII and qP of \#32 (-20 ${ }^{\circ} \mathrm{C}$ under $\left.24 \mathrm{~h} \mathrm{LT}\right)$ and \#42 $\left(-20{ }^{\circ} \mathrm{C}\right.$ under $2 \mathrm{~h} ;-16^{\circ} \mathrm{C}$ 
under $12 \mathrm{~h} ;-8 /-16{ }^{\circ} \mathrm{C}$ under $\left.24 \mathrm{~h} \mathrm{LT}\right)$ were 0 , and NPQ of \#42 (-20 ${ }^{\circ} \mathrm{C}$ under $\left.24 \mathrm{~h}\right)$ was 0 . All these results suggest that clone \#32 may cope with cold stress better than clone \#42.
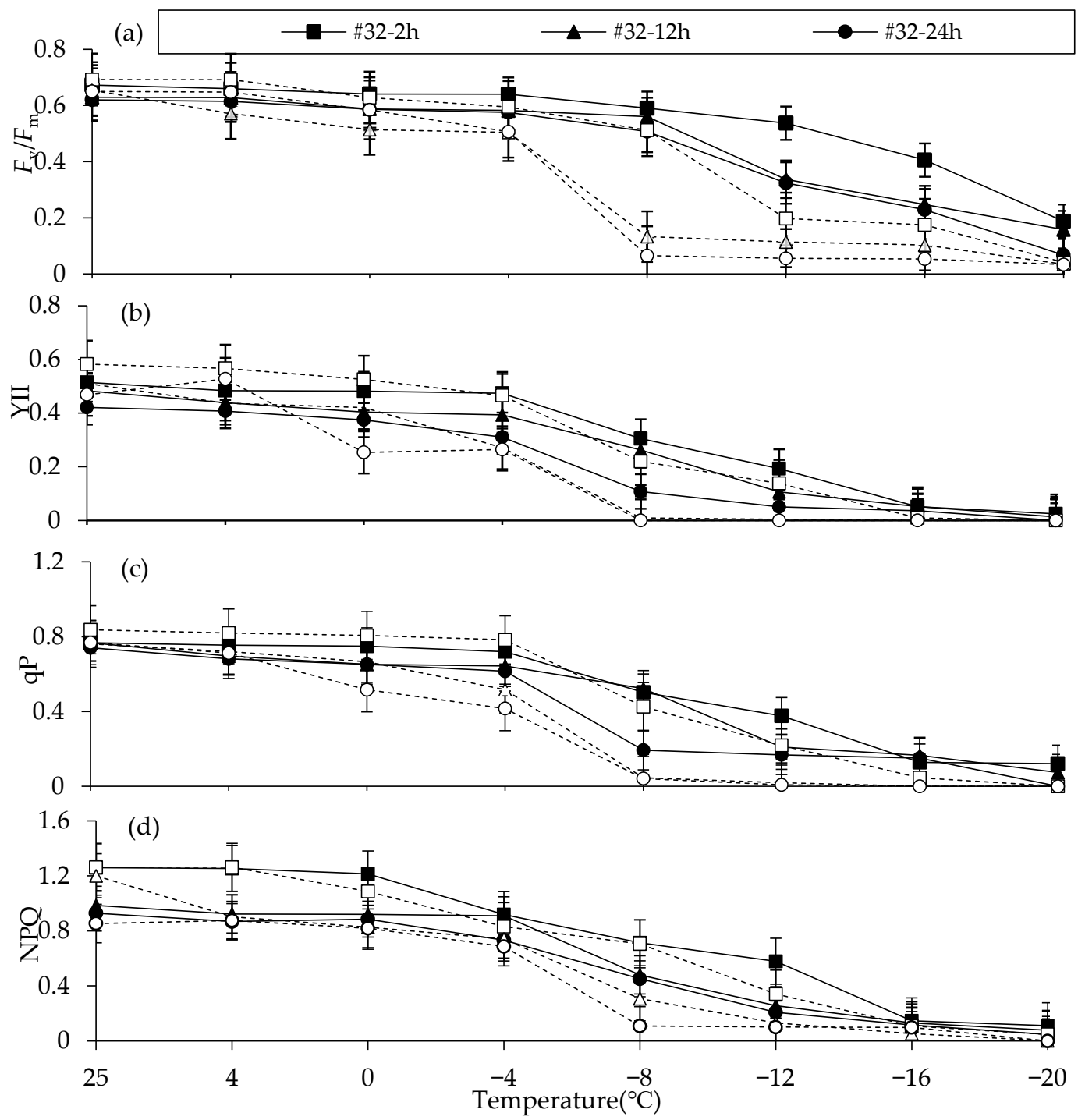

Figure 4. Changes of chlorophyll fluorescence in C. fortunei clones under different low-temperature stress. (a) Changes of $F_{\mathrm{V}} / F_{\mathrm{m}}$ ratio; (b) changes of the effective quantum yield of PSII (YII); (c) changes of photochemical quenching (qP); (d) changes of non-photochemical quenching (NPQ). Each value is the mean \pm standard error, $n=6$.

\subsection{Mesophyll Cells of C. fortunei Needles Undergo Ultrastructural Changes under LTS}

Since we observed eventual structural collapse of needles at very low temperature, we sought to test whether the cellular structure of needles was affected by LTS using electron microscopy. Indeed, we found that the ultrastructure of $C$. fortunei mesophyll cell showed significant changes under decreasing LTS (Figure 5). At $25^{\circ} \mathrm{C}$, the cell nucleus, cell walls, chloroplasts and mitochondria had a normal structure with clearly visible membranes and homogeneous karyoplasm, and distinct nucleoli could also be observed (Figure 5a-f). Large central vacuoles occupied most of the cellular space, squeezing other organelles to the edge (Figure 5a,d,e). A large number of well-developed chloroplasts were distributed along the long axis on the inner side of the plasma membrane, showing dense stroma and regularly stacked grana thylakoids. A few osmiophilic plastoglobules and starch granules appeared in the chloroplasts, which were themselves densely surrounded by mitochondria (Figure 5c,f). 


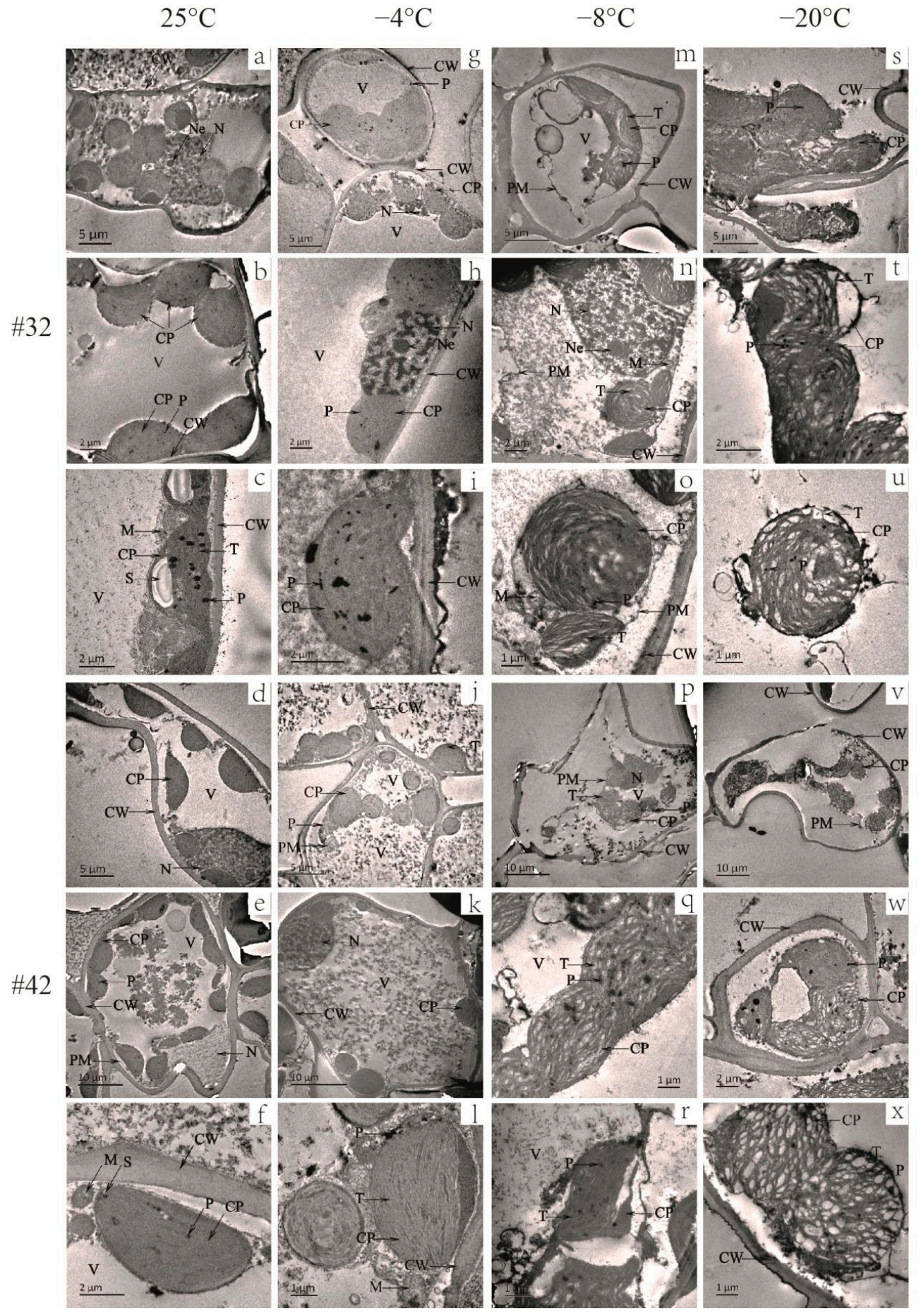

Figure 5. Ultrastructure of chloroplasts in \#32 and \#42 needles under decreasing low-temperature stress (LTS). These images of needles were taken from Advanced Analysis and Test Center in Nanjing Forestry University. (a-c) \#32 at room temperature; (d-f) \#42 at room temperature; $(\mathbf{g}-\mathbf{i}) \# 32$ at $-4{ }^{\circ} \mathrm{C}$ LTS; (j-1) \#42 at $-4{ }^{\circ} \mathrm{C}$ LTS; (m-o) \#32 at $-8{ }^{\circ} \mathrm{C}$ LTS; (p-r) \#42 at $-8{ }^{\circ} \mathrm{C}$ LTS; (s-u) \#32 at $-20{ }^{\circ} \mathrm{C}$ LTS; (v-x) \#42 at $-20^{\circ} \mathrm{C}$ LTS. CP: chloroplast; CW: cell wall; M: mitochondria; N: nucleus; Ne: nucleolus; P: plastoglobuli; PM: plasma membrane; S: starch granule; T: thylakoids; V: vacuole.

When the temperature decreased to $-4{ }^{\circ} \mathrm{C}$, the majority of cell organellar structures remained clear and complete (Figure $5 \mathrm{~g}-1)$. No obvious difference in ultrastructure was observed in needles derived from clone \#32 compared to the control condition $\left(25^{\circ} \mathrm{C}\right)$. However, we did observe that most chloroplasts became swollen. In the chloroplasts, the number of plastoglobules markedly 
increased, whereas starch granules reduced significantly (Figure 5g-i). Additionally, we observed dilated thylakoid lumina. Similar changes, yet to a greater extent, were observed in clone \#42 than in \#32: the cytoplasmic membrane was partly invaginated (Figure 5j), multiple vacuoles were found (Figure 5k) and their inclusion increased sharply, most chloroplasts were swollen into the hemisphere and some moved towards the center of cells (Figure 5j,1) and vacuolizing mitochondria were also visible (Figure 51).

Obvious changes in ultrastructures were observed as the temperature was further reduced to $-8{ }^{\circ} \mathrm{C}$, such as unclear thylakoids, the separation of chloroplasts from the cell wall and serious plasmolysis (Figure $5 \mathrm{~m}-\mathrm{r}$ ). In the cells of \#32, the nucleus was slightly blurred, and vacuole inclusions increased significantly (Figure 5n). The chloroplasts were further swollen and deformed (Figure 5o). Intervals between stroma lamellae, a small amount of plastoglobules as well as vacuolizing mitochondria were visible (Figure 5n,o). The cells of \#42 displayed more serious damage. Most of the mesophyll cells showed a greater degree of plasmolysis (Figure 5p). The cellular structure was scattered, the nucleus blurred, the cell wall folded (Figure 5p) and vacuole membrane ruptured, leading to contents flowing out. Some chloroplasts were swollen, distorted, and even their bilayer membranes were damaged (Figure 5r). Starch granules were not observed in cells, and the number of mitochondria decreased dramatically (Figure 5q,r).

At $-20^{\circ} \mathrm{C}$, the ultrastructures of the two clones had the most severe defects (Figure $5 \mathrm{~s}-\mathrm{x}$ ). Most organelles were collapsed and degraded. The intact structure of chloroplasts was lost. The stroma lamellae were broken, discrete, elongated and thinned, showing a severe filamentous layer structure. Mitochondria were also decomposed and disappeared. Based on these results, we concluded that the ultrastructure of cells indeed responded to cold stress, and the clone (\#32) more resistant to cold stress appeared less affected than the sensitive one (\#42).

\subsection{Chloroplast Size of C. fortunei is Affected by LTS}

Plant photosynthesis depends not only on the increase in the number of chloroplasts in cells, but also on the expansion of their cell surface area [50]. To determine whether the sizes of chloroplasts we observed in mesophyll cells was changed by an increasing degree of LTS, we turned to directly measuring cross-sections of chloroplasts. Under LTS for $24 \mathrm{~h}$, with decreasing temperature, no significant differences in the lengths of the long or short axes of the chloroplasts within each clone were found (Table 4). The cross-section areas of chloroplasts of \#32 and \#42 first ascended and then descended, and the minimum values were 14.55 and $13.25 \mu \mathrm{m}^{2}$ at -8 and $-4{ }^{\circ} \mathrm{C}$ (the temperature with the minimum cross-section area was consistent with the $\mathrm{LT}_{50}$ ), respectively (Table 4 ). Thus, we speculated that as the temperature $\left(>\mathrm{LT}_{50}\right)$ decreased, the cross-section areas of chloroplasts reduced; at $\mathrm{LT}_{50}$ or lower, the integrity of the chloroplast will be destroyed, and the cross-section area of the chloroplast will be further expanded. The cross-section areas of chloroplasts from clone \#32 were not significantly affected by increasing intensity of LTS, while chloroplasts from \#42 did show a significant response to LT $(p<0.05)$ (Table 4). We therefore conclude that, in general, clone \#32, which had stronger cold resistance, had smaller changes to chloroplast size.

Table 4. Effects of low temperature on cross sections of chloroplasts in two clones.

\begin{tabular}{|c|c|c|c|c|c|c|}
\hline \multirow[b]{2}{*}{$\begin{array}{c}\text { Treatment } \\
\text { Temperature }\left({ }^{\circ} \mathrm{C}\right)\end{array}$} & \multicolumn{3}{|c|}{ \#32 } & \multicolumn{3}{|c|}{$\# 42$} \\
\hline & $\begin{array}{l}\text { Length of } \\
\text { Long Axis } \\
\quad(\mu \mathrm{m})\end{array}$ & $\begin{array}{c}\text { Length of } \\
\text { Short Axis } \\
(\mu \mathrm{m})\end{array}$ & $\begin{array}{c}\text { Cross-Section Area } \\
\text { of Chloroplast } \\
\left(\mu \mathrm{m}^{2}\right)\end{array}$ & $\begin{array}{l}\text { Length of } \\
\text { Long Axis } \\
\quad(\mu \mathrm{m})\end{array}$ & $\begin{array}{l}\text { Length of } \\
\text { Short Axis } \\
\quad(\mu \mathrm{m})\end{array}$ & $\begin{array}{c}\text { Cross-Section Area } \\
\text { of Chloroplast } \\
\left(\mu \mathrm{m}^{2}\right)\end{array}$ \\
\hline 25 & $5.39 \pm 0.33 a$ & $3.72 \pm 0.31 \mathrm{a}$ & $15.94 \pm 1.58 \mathrm{a}$ & $6.61 \pm 0.40 \mathrm{a}$ & $3.69 \pm 0.23 a$ & $19.32 \pm 1.87 \mathrm{a}$ \\
\hline-4 & $4.79 \pm 0.30 \mathrm{a}$ & $4.05 \pm 0.29 \mathrm{a}$ & $15.54 \pm 1.71 \mathrm{a}$ & $4.52 \pm 0.43 b$ & $3.58 \pm 0.22 \mathrm{a}$ & $13.25 \pm 1.84 b$ \\
\hline-8 & $5.28 \pm 0.27 a$ & $3.41 \pm 0.42 \mathrm{a}$ & $14.55 \pm 1.86 \mathrm{a}$ & $4.98 \pm 0.27 b$ & $3.69 \pm 0.28 a$ & $14.45 \pm 0.91 \mathrm{bc}$ \\
\hline-20 & $5.06 \pm 0.32 \mathrm{a}$ & $4.33 \pm 0.34 \mathrm{a}$ & $17.29 \pm 2.25 \mathrm{a}$ & $5.30 \pm 0.21 b$ & $4.25 \pm 0.30 \mathrm{a}$ & $17.78 \pm 1.59 \mathrm{c}$ \\
\hline
\end{tabular}

Values are mean \pm standard error, $n=10$, lowercase letters in the same column indicate significant differences $(p<0.05)$. 


\section{Discussion}

Increased tolerance to biotic and abiotic stresses in plants is necessary to increase productivity under conditions with LT, high salinity, limited water supply and so forth [51]. In this study, the physiological responses to cold stress were studied to identify key elements that may be responsible for LT tolerance in C. fortunei.

Plant cell membranes play a crucial role in maintaining a stable intracellular environment [52]. Under LTS, the integrity of the cell membrane is destroyed, causing leakage of intracellular soluble substances and an increase in EL. There is a positive correlation between the rate of lipid peroxidation and EL [53]: the greater the LTS, the greater the relative permeability of plasma membrane and EL. In this study, the EL of $C$. fortunei clones showed a typical rising S-curve in response to decreasing temperatures, with a slow increase in EL between 4 and $0{ }^{\circ} \mathrm{C}$, similar to the results obtained using Salix eriocephala [37]. During initial or mild injury (sublethal dose) and adverse stress of $C$. fortunei, there was a stage in which EL occurred with a slight decrease or no significant change at $0{ }^{\circ} \mathrm{C}$, compared to $4{ }^{\circ} \mathrm{C}$, because of the self-protection mechanism of plants. During the frosting process (from 0 to $-8^{\circ} \mathrm{C}$ ) EL was found to increase sharply, which is consistent with previous reports on Forsythia $\times$ intermedia ('Lynwood Gold' forsythia) cultivars [54]. It might be because at this temperature, the biofilm system is seriously damaged, and its permeability is sharply increased, resulting in a large amount of extravasation of electrolytes [55]. As the temperature was further reduced, we found that EL did not change significantly, which was consistent with research on cherry rootstocks [56]. It is possible that most cell damage had reached the saturation state and caused irreversible damage. Reports in tea leaves [57] and evergreen alpine shrubs [58] showed that the $\mathrm{LT}_{50}$ (at LT) can reflect cold resistance accurately: the lower the value, the stronger the cold resistance of plants. Therefore, according to the $\mathrm{LT}_{50}$ value, we designated \#32 as having the highest cold resistance and \#42 as having the lowest cold resistance.

Our results show that needle shapes and colors changed significantly in response to cold stress, and they were extremely significantly negative $(p<0.01)$ related to cold resistance (temperature) of $C$. fortunei (Appendix A, Table A1). This was similar to results obtained from previous studies on Fagus sylvatica (European beech) [59], in which leaves did not remain freshly green as a result of freezing stress. We found that, with a further decrease of LT $\left(\geq-12^{\circ} \mathrm{C}\right)$ and the prolongation of LT treatment, the chlorophyll contents of our two $C$. fortunei clones reduced by varying degrees. This was similar to studies performed on Eupatorium adenophorum (crofton weed) [60], rice [61] and Dactylis glomerata (orchardgrass) [62], supporting that, under freezing stress, chlorophyll content decreases as temperature decreases. We also found that within a certain temperature range (from 25 to $-12{ }^{\circ} \mathrm{C}$ ), the changes of needle color were related to chlorophyll content (Appendix A, Table A2). It may be that free radicals cause damage to the plant chloroplasts' membrane [63] and inhibit the synthesis of light-harvesting complexes in chloroplast lamellae as well as protochlorophyllide oxidoreductase [64], leading to a blockade in chlorophyll synthesis. On the other hand, LT can enhance chlorophyll degradation and further reduce the chlorophyll content $[65,66]$, resulting in a high degree of plant needle tissue necrosis. Interestingly, we found that chlorophyll content showed a resurgence at -16 and/or $-20^{\circ} \mathrm{C}$. We think this may be caused by needle wilting and excessive water loss, resulting in a high content of chlorophyll per gram of fresh weight, and might be due to a too low temperature, causing the needle to freeze quickly and leaving no time for the chemical reaction. In general, the LT change mechanism of the chlorophyll content is more complex [67].

We found that $F_{\mathrm{v}} / F_{\mathrm{m}}$ continuously decreased as stress increased. This agrees with much of the research reported in Eupatorium adenophorum, sunflower and apricot fruit, which states that LTS can cause damage to the PSII reaction center in plants, resulting in a continuous decline in $F_{\mathrm{v}} / F_{\mathrm{m}}[60,68,69]$. A series of fluorescence parameters, such as yield, $\mathrm{qP}$ and NPQ, related to PSII electron transfer ability also decreased in the leaves of $C$. fortunei under LTS. This shows that LT not only causes changes to the structure of the light harvesting antenna and reaction center, but it also reduces the chemical conversion efficiency of PSII [70] and inhibits the electron transfer of PSII. We speculated that the basic reason may 
be that LT causes the changes to the structure or conformation of the reaction center, light harvesting antenna, electron transfer body and other proteins on the thylakoid membrane, and finally causes the omnidirectional damage and suppression of the PSII reaction center [20]. Fluorescence parameters were closely correlated to the cold resistance of $C$. fortunei (Appendix A, Table A1). The change of $F_{\mathrm{v}} / F_{\mathrm{m}}$ is widely used and relatively clear, making it a suitable indicator of cold tolerance. At the same time, combined with the temperature when $F_{\mathrm{v}} / F_{\mathrm{m}}>0.5$, we speculated that $\# 32$ can tolerate $-12{ }^{\circ} \mathrm{C}$ for $2 \mathrm{~h}$ or $-8^{\circ} \mathrm{C}$ for a long time $(12,24 \mathrm{~h})$. In contrast, $42 \#$ can tolerate $-8^{\circ} \mathrm{C}$ for $2 \mathrm{~h}$ or $-4{ }^{\circ} \mathrm{C}$ for a long time. We also think the tolerable temperature may be close to $\mathrm{LT}_{50}$. Future experiments could include different seasons for a more accurate and detailed record of cold resistance. At the same time, different tissues of $C$. fortunei clones can be sampled to study whether physiological changes might differ across organs.

We found that with increasing cold stress, the cross-section area of chloroplasts decreased first, then increased. Chloroplast enlargement appears to occur in both cold-resistant plants such as Arabidopsis thaliana (thale cress) and cold-sensitive plants such as mung bean [71]. Chloroplasts are believed to be the most sensitive organelles [72]. An osmotic imbalance between stroma and cytoplasm may be the cause of chloroplast swelling [28,73]. Slight swelling of the chloroplasts may reduce the activity of starch degradation enzymes and soluble sugar content, thereby reducing the amount of photosynthetic product in the chloroplast as well as the matrix water potential [28]. At $\mathrm{LT}_{50}$ or lower, the chloroplast further expands, resulting in the loss of its intact structure and disorganization of its outer membrane, resulting in an increase in its area. Our study showed that LTS caused plasmolysis as well as numerous invaginations of the plasma membrane, vacuolation of plastids and mitochondria, condensation of chromatin in the nucleus, multiple vacuoles and an increase in their inclusion in C. fortunei needles. Similar alterations in cellular ultrastructure have been observed by cold stress in leaves of Camellia sinensis (tea) [74], Arabidopsis thaliana [75], winter wheat cv. Volodarka [76], as well as one-year-old young grape plants (Vitis vinifera) [77]. Ultrastructural cold damage to plant cells is significantly similar to the ultrastructural changes in the programmed death process, and the physiological response of plant cells exposed to LT (above-freezing temperatures) also resembles that seen in putative programmed cell death [28]. The reasons for mitochondrial damage might be that mitochondria accumulate a large amount of reactive oxygen species, which could damage mitochondrial cristae, decreasing the mitochondrial energy production rate and the metabolism of mesophyll cells, leaf tissue or the whole plant [78]. The phenomena of multiple vacuoles and their increased inclusion may be related to vacuole-clearing, senescent organelles and cells under LT conditions. Alternatively, it may be a general plant stress response. The nucleus is the regulatory center of physiological and biochemical processes for cells, and damage to the nucleus results in cells being unable to maintain their normal metabolic processes, ultimately leading to cell death [79]. We did find that the majority of cell organellar structures of \#32 and \#42 remained clear and complete at $-4{ }^{\circ} \mathrm{C}$, so we think the needles of both clones were not damaged irreparably and can tolerate $-4{ }^{\circ} \mathrm{C}$ for $24 \mathrm{~h}$. Whereas, the cellular ultrastructure changed obviously at $-8^{\circ} \mathrm{C}$, and for $\# 32$, chloroplasts were swollen, the nucleus was slightly blurred and vacuole inclusions increased (the structures were complete), while those structures (most mesophyll cells, cellular structure, nucleus, cell wall, vacuole membrane, chloroplast) of \#42 were damaged seriously or even destroyed. Therefore, we speculated that \#32 was able to endure at $-8{ }^{\circ} \mathrm{C}$ for $24 \mathrm{~h}$, while $\# 42$ can tolerate $-4{ }^{\circ} \mathrm{C}$ for $24 \mathrm{~h}$, and we think the tolerable temperature may be also close to $\mathrm{LT}_{50}$. In addition, metabolic disruptions induced by environmental factors are manifested in the ultrastructure of cell organelles, and cellular components have varied tolerance to LT [80]. Similarly, under LTS, damage inflicted on the same types of organelles was different between cells, which ensured that cells can maintain normal physiological function for a period of time under external stress, and it may be beneficial to the survival of $C$. fortunei at moderate levels of LTS. At temperatures lower than the $\mathrm{LT}_{50}$, the specific effects of different $\mathrm{LT}$ with small gradients (such as $1^{\circ} \mathrm{C}, 2^{\circ} \mathrm{C}$ ) on the ultrastructural changes of plants need further study. 


\section{Conclusions}

We found the $\mathrm{LT}_{50}$ of 10 tested clones of $\mathrm{C}$. fortunei to be between -4.7 and $-7.8^{\circ} \mathrm{C}$, with $\# 32$ having the lowest value at $-7.8^{\circ} \mathrm{C}$ and $\# 42$ the highest at $-4.7^{\circ} \mathrm{C}$, suggesting that $\# 32$ and $\# 42$ have the strongest and weakest cold resistances, respectively. Furthermore, under LTS, the degree of detrimental effects on needle browning and chlorophyll fluorescence parameters are closely correlated to the amount of cold resistance that a C. fortunei clone has. In a certain temperature range (from 25 to $-12{ }^{\circ} \mathrm{C}$ ), chlorophyll content is closely related to cold resistance. Needle browning is the most sensitive indicator of LTS or of the difference between \#32 and \#42, as needles begin to turn reddish brown above $\mathrm{LT}_{50}$. The changes in chlorophyll are more complex compared to needle browning or other parameters, and chlorophyll contents reduced to varying degrees as the temperature decreased $\left(\geq-12^{\circ} \mathrm{C}\right)$ and then recovered at -16 and/or $-20^{\circ} \mathrm{C}$. Meanwhile, we found that the parameters most closely correlated to the $\mathrm{LT}_{50}$ are $F_{\mathrm{v}} / F_{\mathrm{m}}$ and ultrastructure changes, suggesting that $F_{\mathrm{v}} / F_{\mathrm{m}}$ and ultrastructure changes are more suitable as physiological indicators for cold resistance. Clone $\# 32$ can tolerate $-8^{\circ} \mathrm{C}$ for a long time $(12 \mathrm{~h}, 24 \mathrm{~h})$ or $-12{ }^{\circ} \mathrm{C}$ for a short time $(2 \mathrm{~h})$. Similarly, $\# 42$ can tolerate $-4{ }^{\circ} \mathrm{C}$ for a long time or $-8{ }^{\circ} \mathrm{C}$ for a short time. The physiological states of \#32 were more stable and have wider adaptability to LTS. It may be useful for breeders to breed a cultivar that is more resistant to chilling conditions by inbreeding clone \#32 to pursue and isolate LT-dominant plants or doing more molecular studies between \#42 and \#32.

Author Contributions: Conceptualization, J.X.; formal analysis, Y.Z., Q.Z., M.Z., Z.G., J.Y., J.C. and H.H.; data curation, Y.Z.; writing—original draft, Y.Z., Q.Z. and M.Z.; writing—review and editing, Y.Z. and J.M.; supervision, J.X; funding acquisition, J.X.; project administration, J.X. All authors have read and agreed to the published version of the manuscript.

Funding: This research was funded by the National Forestry and Grassland Administration of China, National Forestry Public Welfare Industry Research Project (Grant No. 201304104), and the Priority Academic Program Development of Jiangsu Higher Education Institutions (PAPD).

Acknowledgments: We would like to give thanks to Jinhui Chen for her experimental help in determining chlorophyll fluorescence parameters, and R.A. Mentink and Zhongjuan Zhang for their careful scientific revisions on the manuscript. We also thank reviewers for insightful comments on this article.

Conflicts of Interest: The authors declare that they have no conflict of interest. 


\section{Appendix A}

Table A1. Correlation analysis of physiological indexes of $C$. fortunei under LT (from 25 to $-20^{\circ} \mathrm{C}$ ).

\begin{tabular}{|c|c|c|c|c|c|c|c|c|c|c|c|}
\hline Clone & Time & Category & Temperature & Browning Index & Chl a & Chl b & Chl & YII & NPQ & $\mathrm{qP}$ & $F_{\mathrm{v}} / F_{\mathrm{m}}$ \\
\hline \multirow{27}{*}{ \#32 } & \multirow{9}{*}{$2 \mathrm{~h}$} & Temperature & \multirow[t]{9}{*}{1.000} & $-0.861^{* *}$ & $0.410 * *$ & 0.197 & $0.432 * *$ & $0.698 * *$ & $0.827^{* *}$ & $0.675^{* *}$ & $0.705^{* *}$ \\
\hline & & Browning Index & & \multirow[t]{8}{*}{1.000} & -0.274 & -0.083 & -0.282 & $-0.739 * *$ & $-0.764 * *$ & $-0.681 * *$ & -0.723 ** \\
\hline & & Chl a & & & 1.000 & $0.377^{* *}$ & $0.855^{* *}$ & 0.268 & 0.464 ** & $0.312 *$ & 0.283 \\
\hline & & Chl b & & & & 1.000 & $0.522 * *$ & 0.080 & 0.116 & -0.007 & 0.152 \\
\hline & & Chl & & & & & \multirow[t]{5}{*}{1.000} & 0.239 & $0.406^{* *}$ & 0.239 & $0.312 *$ \\
\hline & & YII & & & & & & \multirow[t]{4}{*}{1.000} & $0.558 * *$ & 0.797 ** & $0.681 * *$ \\
\hline & & NPQ & & & & & & & 1.000 & $0.659^{* *}$ & $0.543^{* *}$ \\
\hline & & $\mathrm{qP}^{-}$ & & & & & & & & 1.000 & $0.536^{* *}$ \\
\hline & & $F_{\mathrm{v}} / F_{\mathrm{m}}$ & & & & & & & & & 1.000 \\
\hline & \multirow{9}{*}{$12 \mathrm{~h}$} & Temperature & \multirow[t]{9}{*}{1.000} & \multirow{9}{*}{$\begin{array}{c}-0.907^{* *} \\
1.000\end{array}$} & 0.364 * & -0.015 & 0.265 & $0.804 * *$ & $0.811^{* *}$ & $0.855^{* *}$ & $0.736^{* *}$ \\
\hline & & Browning Index & & & -0.288 & 0.054 & -0.202 & $-0.824 * *$ & $-0.799 * *$ & $-0.810 * *$ & $-0.676^{* *}$ \\
\hline & & Chl a & & & 1.000 & 0.275 & $0.848^{* *}$ & 0.239 & 0.240 & $0.287^{*}$ & 0.196 \\
\hline & & Chl b & & & & 1.000 & $0.428^{* *}$ & 0.007 & -0.044 & 0.004 & 0.065 \\
\hline & & Chl & & & & & \multirow[t]{5}{*}{1.000} & 0.188 & 0.175 & 0.221 & 0.188 \\
\hline & & YII & & & & & & 1.000 & $0.778^{* *}$ & $0.868^{* *}$ & $0.681 * *$ \\
\hline & & NPQ & & & & & & & 1.000 & $0.820 * *$ & $0.691 * *$ \\
\hline & & $\mathrm{qP}^{-}$ & & & & & & & & 1.000 & $0.664^{* *}$ \\
\hline & & $F_{\mathrm{v}} / F_{\mathrm{m}}$ & & & & & & & & & 1.000 \\
\hline & \multirow{9}{*}{$24 \mathrm{~h}$} & Temperature & \multirow[t]{9}{*}{1.000} & $-0.906 * *$ & 0.121 & 0.050 & 0.114 & $0.824 * *$ & $0.686^{* *}$ & $0.791 * *$ & $0.834^{* *}$ \\
\hline & & Browning Index & & \multirow[t]{8}{*}{1.000} & -0.047 & -0.047 & -0.059 & $-0.836^{* *}$ & $-0.710^{* *}$ & $-0.779 * *$ & $-0.819^{* *}$ \\
\hline & & Chl a & & & 1.000 & $0.606^{* *}$ & $0.916^{* *}$ & 0.047 & -0.062 & 0.048 & 0.029 \\
\hline & & Chl b & & & & 1.000 & $0.696^{* *}$ & 0.052 & -0.030 & 0.000 & 0.004 \\
\hline & & Chl & & & & & 1.000 & 0.055 & -0.062 & 0.070 & 0.036 \\
\hline & & YII & & & & & & 1.000 & $0.568 * *$ & $0.793 * *$ & $0.842 * *$ \\
\hline & & NPQ & & & & & & & 1.000 & $0.601^{* *}$ & $0.652 * *$ \\
\hline & & $\mathrm{qP}$ & & & & & & & & 1.000 & $0.694^{* *}$ \\
\hline & & $F_{\mathrm{v}} / F_{\mathrm{m}}$ & & & & & & & & & 1.000 \\
\hline
\end{tabular}


Table A1. Cont.

\begin{tabular}{|c|c|c|c|c|c|c|c|c|c|c|c|}
\hline Clone & Time & Category & Temperature & Browning Index & Chl a & Chl b & Chl & YII & NPQ & $\mathrm{qP}$ & $F_{\mathrm{v}} / F_{\mathrm{m}}$ \\
\hline \multirow{27}{*}{$\# 42$} & \multirow{9}{*}{$2 \mathrm{~h}$} & Temperature & 1.000 & $-0.865^{* *}$ & $0.592 * *$ & $0.497 * *$ & $0.615^{* *}$ & 0.916 ** & $0.797 * *$ & $0.830 * *$ & $0.870 * *$ \\
\hline & & Browning Index & & 1.000 & $-0.559 * *$ & $-0.404 *$ & $-0.573^{* *}$ & $-0.823 * *$ & $-0.772 * *$ & $-0.841 * *$ & $-0.794 * *$ \\
\hline & & Chl a & & & 1.000 & $0.518^{* *}$ & $0.918^{* *}$ & $0.586^{* *}$ & $0.521 * *$ & $0.510^{* *}$ & $0.541^{* *}$ \\
\hline & & $\mathrm{Chl} \mathrm{b}$ & & & & 1.000 & 0.603 ** & $0.524 * *$ & $0.400 * *$ & $0.403 * *$ & $0.457 * *$ \\
\hline & & $\mathrm{Chl}$ & & & & & 1.000 & $0.642 * *$ & $0.540 * *$ & $0.544 * *$ & $0.560 * *$ \\
\hline & & YII & & & & & & 1.000 & 0.740 ** & $0.820 * *$ & $0.855^{* *}$ \\
\hline & & NPQ & & & & & & & 1.000 & 0.723 ** & 0.679 ** \\
\hline & & $\mathrm{qP}$ & & & & & & & & 1.000 & $0.787^{* *}$ \\
\hline & & $F_{\mathrm{v}} / F_{\mathrm{m}}$ & & & & & & & & & 1.000 \\
\hline & \multirow{9}{*}{$12 \mathrm{~h}$} & Temperature & 1.000 & $-0.898^{* *}$ & 0.265 & 0.084 & 0.235 & $0.842 * *$ & $0.828 * *$ & $0.832 * *$ & $0.790 * *$ \\
\hline & & Browning Index & & 1.000 & -0.250 & -0.078 & -0.226 & $-0.787^{* *}$ & $-0.735^{* *}$ & -0.787 ** & $-0.688 * *$ \\
\hline & & Chl a & & & 1.000 & $0.613^{* *}$ & 0.949 ** & 0.302 * & 0.287 * & 0.207 & 0.279 \\
\hline & & $\mathrm{Chl} \mathrm{b}$ & & & & 1.000 & 0.664 ** & 0.117 & 0.073 & 0.076 & 0.095 \\
\hline & & Chl & & & & & 1.000 & 0.272 & 0.250 & 0.177 & 0.258 \\
\hline & & YII & & & & & & 1.000 & 0.776 ** & $0.857^{* *}$ & $0.802 * *$ \\
\hline & & NPQ & & & & & & & 1.000 & $0.725^{* *}$ & $0.800^{* *}$ \\
\hline & & $\mathrm{qP}^{2}$ & & & & & & & & 1.000 & $0.801 * *$ \\
\hline & & $F_{\mathrm{v}} / F_{\mathrm{m}}$ & & & & & & & & & 1.000 \\
\hline & \multirow{9}{*}{$24 \mathrm{~h}$} & Temperature & 1.000 & $-0.921 * *$ & 0.190 & -0.004 & 0.159 & $0.756^{* *}$ & 0.691 ** & $0.795^{* *}$ & $0.796^{* *}$ \\
\hline & & Browning Index & & 1.000 & -0.192 & 0.000 & -0.176 & $-0.717^{* *}$ & -0.693 ** & $-0.762 * *$ & -0.770 ** \\
\hline & & Chl a & & & 1.000 & $0.425^{* *}$ & $0.891 * *$ & 0.291 & $0.303 *$ & 0.207 & 0.254 \\
\hline & & Chl b & & & & 1.000 & 0.534 ** & 0.129 & 0.033 & -0.035 & 0.142 \\
\hline & & $\mathrm{Chl}$ & & & & & 1.000 & 0.299 & 0.258 & 0.200 & 0.27 \\
\hline & & YII & & & & & & 1.000 & 0.652 ** & $0.774^{* *}$ & $0.798^{* *}$ \\
\hline & & NPQ & & & & & & & 1.000 & 0.633 ** & $0.583 * *$ \\
\hline & & $\mathrm{qP}$ & & & & & & & & 1.000 & $0.652 * *$ \\
\hline & & $F_{\mathrm{v}} / F_{\mathrm{m}}$ & & & & & & & & & 1.000 \\
\hline
\end{tabular}

Correlation analysis through double variables mode, and Kendall's tau-b method was used to test the statistical significance of the difference. LT, low temperature; Chl, Chlorophyll a $+\mathrm{b}$; Chl a, Chlorophyll a; Chl b, Chlorophyll b; ${ }^{* *}$, highly significant correlation; ${ }^{*}$, significant correlation; - , negative correlation. 
Table A2. Correlation analysis of physiological indexes of $C$. fortunei under LT (from 25 to $-12{ }^{\circ} \mathrm{C}$ ).

\begin{tabular}{|c|c|c|c|c|c|c|c|c|c|c|c|}
\hline Clone & Time & Category & Temperature & Browning Index & Chl a & Chl b & Chl & YII & NPQ & $\mathrm{qP}$ & $F_{\mathrm{v}} / F_{\mathrm{m}}$ \\
\hline \multirow{27}{*}{$\# 32$} & \multirow{9}{*}{$2 \mathrm{~h}$} & Temperature & \multirow[t]{9}{*}{1.000} & $-0.747^{* *}$ & $0.633 * *$ & $0.494^{* *}$ & \multirow{9}{*}{$\begin{array}{c}0.731^{* *} \\
-0.546^{* *} \\
0.830^{* *} \\
0.451^{* *} \\
1.000\end{array}$} & \multirow{9}{*}{$\begin{array}{c}0.494^{* *} \\
-0.529^{* *} \\
0.346^{*} \\
0.281 \\
0.359^{*} \\
1.000\end{array}$} & \multirow{9}{*}{$\begin{array}{c}0.758^{* *} \\
-0.685^{* *} \\
0.647^{* *} \\
0.268 \\
0.582^{* *} \\
0.307 \\
1.000\end{array}$} & \multirow{9}{*}{$\begin{array}{c}0.466^{* *} \\
-0.469^{*} \\
0.386^{*} \\
0.085 \\
0.320 \\
0.699 * * \\
0.451^{* *} \\
1.000\end{array}$} & $0.578^{* *}$ \\
\hline & & Browning Index & & \multirow{8}{*}{1.000} & \multirow{8}{*}{$\begin{array}{c}-0.442 * \\
1.000\end{array}$} & \multirow{8}{*}{$\begin{array}{c}-0.373 \\
0.281 \\
1.000\end{array}$} & & & & & $-0.598 * *$ \\
\hline & & Chl a & & & & & & & & & 0.294 \\
\hline & & $\mathrm{Chl} \mathrm{b}$ & & & & & & & & & $0.412 *$ \\
\hline & & Chl & & & & & & & & & $0.412 *$ \\
\hline & & YII & & & & & & & & & 0.556 ** \\
\hline & & NPQ & & & & & & & & & $0.359 *$ \\
\hline & & $\mathrm{qP}^{-}$ & & & & & & & & & 0.307 \\
\hline & & $F_{\mathrm{v}} / F_{\mathrm{m}}$ & & & & & & & & & 1.000 \\
\hline & \multirow{9}{*}{$12 \mathrm{~h}$} & Temperature & \multirow[t]{9}{*}{1.000} & $-0.859 * *$ & \multirow{9}{*}{$\begin{array}{c}0.647^{* *} \\
-0.486^{* *} \\
1.000\end{array}$} & \multirow{9}{*}{$\begin{array}{c}0.271 \\
-0.187 \\
0.320 \\
1.000\end{array}$} & \multirow{9}{*}{$\begin{array}{c}0.550 * * \\
-0.411^{*} \\
0.830 * * \\
0.490^{* *} \\
1.000\end{array}$} & \multirow{9}{*}{$\begin{array}{c}0.675^{* *} \\
-0.680^{* *} \\
0.386^{*} \\
0.255 \\
0.373^{*} \\
1.000\end{array}$} & \multirow{9}{*}{$\begin{array}{c}0.712^{* *} \\
-0.667 * * \\
0.367 * \\
0.157 \\
0.328 \\
0.643 \text { ** } \\
1.000\end{array}$} & \multirow{9}{*}{$\begin{array}{c}0.810^{* *} \\
-0.712^{* *} \\
0.498^{* *} \\
0.197 \\
0.433^{*} \\
0.813^{* *} \\
0.770^{* *} \\
1.000\end{array}$} & $0.605^{* *}$ \\
\hline & & Browning Index & & 1.000 & & & & & & & $-0.501^{* *}$ \\
\hline & & Chl a & & & & & & & & & $0.373^{*}$ \\
\hline & & Chl b & & & & & & & & & $0.346^{*}$ \\
\hline & & Chl & & & & & & & & & $0.412 *$ \\
\hline & & YII & & & & & & & & & 0.516 ** \\
\hline & & NPQ & & & & & & & & & $0.577^{* *}$ \\
\hline & & $\mathrm{qP}^{2}$ & & & & & & & & & $0.538 * *$ \\
\hline & & $F_{\mathrm{v}} / F_{\mathrm{m}}$ & & & & & & & & & 1.000 \\
\hline & \multirow{9}{*}{$24 \mathrm{~h}$} & Temperature & \multirow[t]{9}{*}{1.000} & $-0.863 * *$ & \multirow{9}{*}{$\begin{array}{c}0.772 \text { ** } \\
-0.646^{* *} \\
1.000\end{array}$} & $0.576^{* *}$ & $0.763 * *$ & $0.731^{* *}$ & $0.550 * *$ & $0.712 * *$ & $0.717^{* *}$ \\
\hline & & Browning index & & 1.000 & & $-0.606^{* *}$ & $-0.672^{* *}$ & $-0.781 * *$ & $-0.555^{* *}$ & $-0.700 * *$ & $-0.691 * *$ \\
\hline & & Chl a & & & & $0.581^{* *}$ & $0.901^{* *}$ & $0.556^{* *}$ & 0.294 & $0.510 * *$ & $0.542 * *$ \\
\hline & & $\mathrm{Chl} \mathrm{b}$ & & & & 1.000 & $0.691^{* *}$ & $0.541^{* *}$ & 0.317 & $0.415 *$ & $0.462 * *$ \\
\hline & & Chl & & & & & 1.000 & $0.572 * *$ & 0.296 & $0.553 * *$ & $0.559 * *$ \\
\hline & & YII & & & & & & 1.000 & $0.373 *$ & $0.735^{* *}$ & $0.778 * *$ \\
\hline & & NPQ & & & & & & & 1.000 & $0.378 *$ & $0.490 * *$ \\
\hline & & $\mathrm{qP}$ & & & & & & & & 1.000 & $0.536^{* *}$ \\
\hline & & $F_{\mathrm{v}} / F_{\mathrm{m}}$ & & & & & & & & & 1.000 \\
\hline
\end{tabular}


Table A2. Cont.

\begin{tabular}{|c|c|c|c|c|c|c|c|c|c|c|c|}
\hline Clone & Time & Category & Temperature & Browning Index & Chl a & Chl b & Chl & YII & NPQ & $\mathrm{qP}$ & $F_{\mathrm{v}} / F_{\mathrm{m}}$ \\
\hline \multirow{27}{*}{$\# 42$} & \multirow{9}{*}{$2 \mathrm{~h}$} & Temperature & 1.000 & $-0.752 * *$ & $0.661 * *$ & $0.586^{* *}$ & 0.691 ** & $0.870 * *$ & 0.703 ** & $0.712 * *$ & $0.838^{* *}$ \\
\hline & & Browning index & & 1.000 & $-0.680 * *$ & $-0.446^{*}$ & $-0.673^{* *}$ & $-0.697 * *$ & $-0.652 * *$ & -0.735 ** & $-0.735^{* *}$ \\
\hline & & Chl a & & & 1.000 & $0.538^{* *}$ & $0.931^{* *}$ & $0.634^{* *}$ & $0.488^{* *}$ & $0.498^{* *}$ & $0.590 * *$ \\
\hline & & $\mathrm{Chl} \mathrm{b}$ & & & & 1.000 & $0.612 * *$ & $0.590 * *$ & $0.391 *$ & $0.375 *$ & $0.493 * *$ \\
\hline & & $\mathrm{Chl}$ & & & & & 1.000 & $0.708^{* *}$ & $0.497^{* *}$ & $0.533 * *$ & $0.625 * *$ \\
\hline & & YII & & & & & & 1.000 & $0.581 * *$ & $0.682 * *$ & 0.826 ** \\
\hline & & NPQ & & & & & & & 1.000 & 0.550 ** & $0.563 * *$ \\
\hline & & $\mathrm{qP}$ & & & & & & & & 1.000 & $0.704^{* *}$ \\
\hline & & $F_{\mathrm{v}} / F_{\mathrm{m}}$ & & & & & & & & & 1.000 \\
\hline & \multirow{9}{*}{$12 \mathrm{~h}$} & Temperature & 1.000 & $-0.847^{* *}$ & $0.675^{* *}$ & $0.482 * *$ & $0.647^{* *}$ & $0.775^{* *}$ & $0.803 * *$ & $0.758^{* *}$ & $0.761^{* *}$ \\
\hline & & Browning index & & 1.000 & $-0.691 * *$ & $-0.482 * *$ & $-0.676^{* *}$ & -0.708 ** & $-0.663 * *$ & -0.691 ** & -0.633 ** \\
\hline & & Chl a & & & 1.000 & $0.669 * *$ & $0.961 * *$ & 0.630 ** & 0.656 ** & $0.464^{* *}$ & $0.564^{* *}$ \\
\hline & & Chl b & & & & 1.000 & $0.708^{* *}$ & $0.454^{* *}$ & $0.428 *$ & $0.380 *$ & 0.467 ** \\
\hline & & Chl & & & & & 1.000 & $0.616^{* *}$ & $0.616^{\text {** }}$ & $0.451 * *$ & 0.551 ** \\
\hline & & YII & & & & & & 1.000 & 0.730 ** & $0.761 * *$ & 0.803 ** \\
\hline & & NPQ & & & & & & & 1.000 & $0.643^{* *}$ & 0.796 ** \\
\hline & & $\mathrm{qP}^{2}$ & & & & & & & & 1.000 & 0.800 ** \\
\hline & & $F_{\mathrm{v}} / F_{\mathrm{m}}$ & & & & & & & & & 1.000 \\
\hline & \multirow{9}{*}{$24 \mathrm{~h}$} & Temperature & 1.000 & $-0.863 * *$ & $0.633^{* *}$ & 0.307 & $0.619^{* *}$ & $0.747^{* *}$ & $0.605^{* *}$ & $0.717^{* *}$ & $0.842 * *$ \\
\hline & & Browning Index & & 1.000 & $-0.646^{* *}$ & -0.324 & $-0.661 * *$ & $-0.696^{* *}$ & $-0.616^{* *}$ & $-0.667^{* *}$ & $-0.811^{* *}$ \\
\hline & & Chl a & & & 1.000 & $0.380 *$ & $0.882 * *$ & $0.523^{* *}$ & $0.634^{* *}$ & $0.554^{* *}$ & $0.569 * *$ \\
\hline & & Chl b & & & & 1.000 & 0.498 ** & $0.366 *$ & 0.223 & 0.232 & $0.420 *$ \\
\hline & & $\mathrm{Chl}$ & & & & & 1.000 & $0.578^{* *}$ & $0.595^{* *}$ & $0.581 * *$ & $0.634 * *$ \\
\hline & & YII & & & & & & 1.000 & $0.564^{* *}$ & $0.723^{* *}$ & $0.826^{* *}$ \\
\hline & & NPQ & & & & & & & 1.000 & $0.528 * *$ & $0.464 * *$ \\
\hline & & $\mathrm{qP}$ & & & & & & & & 1.000 & $0.620 * *$ \\
\hline & & $F_{\mathrm{v}} / F_{\mathrm{m}}$ & & & & & & & & & 1.000 \\
\hline
\end{tabular}

Correlation analysis through double variables mode, and Kendall's tau-b method was used to test the statistical significance of the difference. LT, low temperature; Chl, Chlorophyll a $+\mathrm{b}$; Chl a, Chlorophyll a; Chl b, Chlorophyll b; ${ }^{* *}$, highly significant correlation; ${ }^{*}$, significant correlation; - , negative correlation. 


\section{References}

1. Anderson, J.A.; Taliaferro, C.M. Freeze tolerance of seed-producing turf bermudagrasses. Crop Sci. 2002, 42, 190-192. [PubMed]

2. Levitt, J. Responses of Plants to Environmental Stress, 2nd ed.; Academic Press: New York, NY, USA, 1980; pp. 23-64.

3. Huang, B.; DaCosta, M.; Jiang, Y. Research advances in mechanisms of turfgrass tolerance to abiotic stresses: From physiology to molecular biology. Crit. Rev. Plant Sci. 2014, 33, 141-189. [CrossRef]

4. Xin, Z.; Browse, J. Cold comfort farm: The acclimation of plants to freezing temperatures. Plant Cell Environ. 2000, 23, 893-902. [CrossRef]

5. Steponkus, P.L. Role of the plasma membrane in freezing injury and cold acclimation. Annu. Rev. Plant Physiol. 1984, 35, 543-584. [CrossRef]

6. Hausman, J.F.; Evers, D.; Thiellement, H.; Jouve, L. Compared responses of poplar cuttings and in vitro raised shoots to short-term chilling treatments. Plant Cell Rep. 2000, 19, 954-960. [CrossRef]

7. Campos, P.S.; Nia Quartin, V.; Chicho Ramalho, J.; Nunes, M.A. Electrolyte leakage and lipid degradation account for cold sensitivity in leaves of Coffea sp. plants. J. Plant Physiol. 2003, 160, 283-292. [CrossRef]

8. Zhou, B.; Guo, Z. Calcium is involved in the abscisic acid--induced ascorbate peroxidase, superoxide dismutase and chilling resistance in Stylosanthes guianensis. Biol. Plantarum 2009, 53, 63-68. [CrossRef]

9. Wright, M.; Simon, E.W. Chilling injury in cucumber leaves. J. Exp. Bot. 1973, 24, 400-411. [CrossRef]

10. Reyes-Díaz, M.; Ulloa, N.; Zuniga-Feest, A.; Gutiérrez, A.; Gidekel, M.; Alberdi, M.; Corcuera, L.J.; Bravo, L.A. Arabidopsis thaliana avoids freezing by supercooling. J. Exp. Bot. 2006, 57, 3687-3696. [CrossRef]

11. Venn, S.E.; Morgan, J.W.; Lord, J.M. Foliar freezing resistance of Australian alpine plants over the growing season. Austral. Ecol. 2013, 38, 152-161. [CrossRef]

12. Bannister, P. Godley review: A touch of frost? Cold hardiness of plants in the southern hemisphere. New Zeal. J. Bot. 2007, 45, 1-33. [CrossRef]

13. Renaut, J.; Hoffmann, L.; Hausman, J.F. Biochemical and physiological mechanisms related to cold acclimation and enhanced freezing tolerance in poplar plantlets. Physiol. Plantarum 2005, 125, 82-94. [CrossRef]

14. Marian, C.O.; Krebs, S.L.; Arora, R. Dehydrin variability among rhododendron species: A 25-kDa dehydrin is conserved and associated with cold acclimation across diverse species. New Phytol. 2004, 161, 773-780. [CrossRef]

15. Croft, H.; Chen, J.M.; Luo, X.; Bartlett, P.; Chen, B.; Staebler, R.M. Leaf chlorophyll content as a proxy for leaf photosynthetic capacity. Global Change Biol. 2017, 23, 3513-3524. [CrossRef]

16. Inoue, Y.; Guérif, M.; Baret, F.; Skidmore, A.; Gitelson, A.; Schlerf, M.; Darvishzadeh, R.; Olioso, A. Simple and robust methods for remote sensing of canopy chlorophyll content: A comparative analysis of hyperspectral data for different types of vegetation. Plant Cell Environ. 2016, 39, 2609-2623. [CrossRef] [PubMed]

17. Liu, Y.; Wang, T.; Fang, S.; Zhou, M.; Qin, J. Responses of morphology, gas exchange, photochemical activity of photosystem II, and antioxidant balance in Cyclocarya paliurus to light spectra. Front Plant Sci. 2018, 9, 1704. [CrossRef]

18. Zhang, L.; Ren, J.; Li, T.; Wang, A.; Tan, D. De novo transcriptome sequencing of cold-treated Kentucky bluegrass (Poa pratensis) and analysis of the genes involved in cold tolerance. J. Hort. 2016, 3, 1-9.

19. Kalaji, H.M.; Bosa, K.; Kościelniak, J.; Hossain, Z. Chlorophyll a fluorescence-a useful tool for the early detection of temperature stress in spring barley (Hordeum vulgare L.). OMICS 2011, 15, 925-934. [CrossRef]

20. Kalaji, H.M.; Bosa, K.; Kościelniak, J.; Żuk-Gołaszewska, K. Effects of salt stress on photosystem II efficiency and $\mathrm{CO}_{2}$ assimilation of two Syrian barley landraces. Environ. Exp. Bot. 2011, 73, 64-72. [CrossRef]

21. Woolery, P.O.; Schmal, J.L.; Davis, A.S. Evaluation of chlorophyll fluorescence as an indicator of dehydration stress in American chestnut seedlings. NPJ 2010, 11, 27-32. [CrossRef]

22. Su, L.; Dai, Z.; Li, S.; Xin, H.P. A novel system for evaluating drought-cold tolerance of grapevines using chlorophyll fluorescence. BMC Plant Biol. 2015, 15, 82. [CrossRef] [PubMed]

23. Rizza, F.; Pagani, D.; Stanca, A.M.; Cattivelli, L. Use of chlorophyll fluorescence to evaluate the cold acclimation and freezing tolerance of winter and spring oats. Plant Breed. 2001, 120, 389-396. [CrossRef]

24. Kalaji, H.M.; Schansker, G.; Ladle, R.J.; Goltsev, V.; Bosa, K.; Allakhverdiev, S.I.; Brestic, M.; Bussotti, F.; Calatayud, A.; Dąbrowski, P. Frequently asked questions about in vivo chlorophyll fluorescence: Practical issues. Photosynth. Res. 2014, 122, 121-158. [CrossRef] [PubMed] 
25. Kimball, S.L.; Salisbury, F.B. Ultrastructural changes of plants exposed to low temperatures. Am. J. Bot. 1973, 60, 1028-1033. [CrossRef]

26. McKay, H.M. Electrolyte leakage from fine roots of conifer seedlings: A rapid index of plant vitality following cold storage. Can. J. Forest Res. 1992, 22, 1371-1377. [CrossRef]

27. Saropulos, A.S.; Drennan, D.S.H. Ultrastructural alterations in mesophyll and bundle sheath chloroplasts of two maize cultivars in response to chilling at high irradiance. Biol. Plantarum 2007, 51, 690-698. [CrossRef]

28. Kratsch, H.A.; Wise, R.R. The ultrastructure of chilling stress. Plant Cell Environ. 2000, 23, 337-350. [CrossRef]

29. Chai, Z.; Tan, W.; Li, Y.; Yan, L.; Yuan, H.; Li, Z. Generalized nonlinear height-diameter models for a Cryptomeria fortunei plantation in the Pingba region of Guizhou Province, China. Web Ecol. 2018, 18, $29-35$. [CrossRef]

30. Fan, J.Y.; Tan, D.; Jiang, L.; Qin, W. Research on the tree biomass and productivity of Cryptomeria fortunei Hooibrenk plantation. J. Fujian Forestry Sci. Tech. 2011, 38, 1-5. (in Chinese).

31. Xie, Y.; Huang, Q.; Yang, F.; Lei, C. Chemical variation in essential oil of Cryptomeria fortunei from various areas of China. Ind. Crop Prod. 2012, 36, 308-312. [CrossRef]

32. Reinikainen, J.; Huttunen, $\mathrm{S}$. The level of injury and needle ultrastructure of acid rain-irrigated pine and spruce seedlings after low temperature treatmen. New Phytol. 1989, 112, 29-39. [CrossRef]

33. Rikala, R.; Repo, T. Frost resistance and frost damage in Pinus sylvestris seedlings during shoot elongation. Scand. J. For. Res. 1987, 2, 433-440. [CrossRef]

34. Gao, A.; Jiang, S.; Zhao, X.; Deng, J.; Sha, S.; Liu, Z.; Zhang, M. Study on the hardness of apple cultivars. Journal of fruit science 2000, 17, 17-21. (in Chinese).

35. Nie, C.J.; Zhang, K.L.; Deng, C.G.; Yang, Y.Z. Study on the frost resistance of several tree species in Guizhou. Guizhou For. Sci. Tech. 2013, 41, 1-4. (in Chinese).

36. Rapacz, M.; Woźniczka, A. A selection tool for freezing tolerance in common wheat using the fast chlorophyll a fluorescence transient. Plant Breed. 2009, 128, 227-234. [CrossRef]

37. Tsarouhas, V.; Kenney, W.A.; Zsuffa, L. Application of two electrical methods for the rapid assessment of freezing resistance in Salix eriocephala. Biomass Bioenerg. 2000, 19, 165-175. [CrossRef]

38. Ma, Y.Y.; Zhang, Y.L.; Shao, H.; Lu, J. Differential physio-biochemical responses to cold stress of cold-tolerant and non-tolerant grapes (Vitis L.) from China. J. Agron. Crop Sci. 2010, 196, 212-219. [CrossRef]

39. Huang, H.; Jian, Q.; Jiang, Y.; Duan, X.; Qu, H. Enhanced chilling tolerance of banana fruit treated with malic acid prior to low-temperature storage. Postharvest Biol. Tec. 2016, 111, 209-213. [CrossRef]

40. Janácek, J.; Prásil, I. Quantification of plant frost injury by nonliner fitting of an S-shaped function. Cryo Letters 1991, 12, 47-52.

41. Lichtenthaler, H.K.; Wellburn, A.R. Determinations of total carotenoids and chlorophylls a and b of leaf extracts in different solvents. Biochem. Soc. T. 1983, 11, 591-592. [CrossRef]

42. Cheng, T.; Shi, J.; Dong, Y.; Ma, Y.; Peng, Y.; Hu, X.; Chen, J. Hydrogen sulfide enhances poplar tolerance to high-temperature stress by increasing $\mathrm{S}$-nitrosoglutathione reductase (GSNOR) activity and reducing reactive oxygen/nitrogen damage. Plant Growth Regul. 2018, 84, 11-23. [CrossRef]

43. Graham, L.; Orenstein, J.M. Processing tissue and cells for transmission electron microscopy in diagnostic pathology and research. Nat. Protoc. 2007, 2, 2439. [CrossRef] [PubMed]

44. Hussain, S.; Iqbal, N.; Brestic, M.; Raza, M.A.; Pang, T.; Langham, D.R.; Safdar, M.E.; Ahmed, S.; Wen, B.; Gao, Y.; et al. Changes in morphology, chlorophyll fluorescence performance and Rubisco activity of soybean in response to foliar application of ionic titanium under normal light and shade environment. Sci. Total Environ. 2019, 658, 626-637. [CrossRef] [PubMed]

45. Costa, E.; Silva, F.; Shvaleva, A.; Broetto, F.; Ortuno, M.F.; Rodrigues, M.L.; Almeida, M.H.; Chaves, M.M.; Pereira, J.S. Acclimation to short-term low temperatures in two Eucalyptus globulus clones with contrasting drought resistance. Tree Physiol. 2009, 29, 77-86. [CrossRef]

46. Cocozza, C.; Lasserre, B.; Giovannelli, A.; Castro, G.; Fragnelli, G.; Tognetti, R. Low temperature induces different cold sensitivity in two poplar clones (Populus $\times$ canadensis Mönch 'I-214' and P. deltoides Marsh.'Dvina'). J. Exp. Bot. 2009, 60, 3655-3664. [CrossRef] [PubMed]

47. Linsley-Noakes, G.C.; Allan, P. Effects of winter temperatures on flower development in two clones of kiwifruit (Actinidia deliciosa (A. Chev.) CF Liang et AR Ferguson). Sci. Hortic. (Amsterdam) 1987, 33, 249-260. [CrossRef] 
48. Thomashow, M.F. So what's new in the field of plant cold acclimation? Lots! Plant Physiol. 2001, 125, 89-93. [CrossRef]

49. Gorsuch, P.A.; Pandey, S.; Atkin, O.K. Temporal heterogeneity of cold acclimation phenotypes in Arabidopsis leaves. Plant Cell Environ. 2010, 33, 244-258. [CrossRef]

50. Bondada, B.R.; Oosterhuis, D.M.; Wullschleger, S.D.; Kim, K.S.; Harris, W.M. Anatomical considerations related to photosynthesis in cotton (Gossypium hirsutum L.) leaves, bracts, and the capsule wall. J. Exp. Bot. 1994, 45, 111-118. [CrossRef]

51. Latef, A.A.H.A.; Chaoxing, H. Arbuscular mycorrhizal influence on growth, photosynthetic pigments, osmotic adjustment and oxidative stress in tomato plants subjected to low temperature stress. Acta Physiol. Plant. 2011, 33, 1217-1225. [CrossRef]

52. Polle, A.; Otter, T.; Seifert, F. Apoplastic peroxidases and lignification in needles of Norway spruce (Picea abies L.). Plant Physiol. 1994, 106, 53-60. [CrossRef] [PubMed]

53. Lukatkin, A.S. Contribution of oxidative stress to the development of cold-induced damage to leaves of chilling-sensitive plants: 3 . Injury of cell membranes by chilling temperatures. Russ. J. Plant Physl+ 2003, 50, 243-246. [CrossRef]

54. Marosz, A.; Nogowska, A. Effect of calcium nitrate foliar spray on the calcium content, growth and freezing tolerance of Forsythia $\times$ Intermedia cultivars. J. Plant. Nutr. 2018, 41, 2606-2614. [CrossRef]

55. Huang, Z.; Zhang, X.; Jiang, S.; Qin, M.; Zhao, N.; Lang, L.; Liu, Y.; Tian, Z.; Liu, X.; Wang, Y. Analysis of cold resistance and identification of SSR markers linked to cold resistance genes in Brassica rapa L. Breed. Sci. 2017, 3, 213-220. [CrossRef] [PubMed]

56. Li, B.; Liu, C.; Yang, R.; Liu, Q. Study on the cold resistance of cherry rootstocks. J. Fruit Sci. 2006, 2, 196-199. (in Chinese).

57. Lu, Y.; Hu, Y.; Li, P. Consistency of electrical and physiological properties of tea leaves on indicating critical cold temperature. Biosyst. Eng. 2017, 159, 89-96. [CrossRef]

58. Venn, S.E.; Green, K. Evergreen alpine shrubs have high freezing resistance in spring, irrespective of snowmelt timing and exposure to frost: An investigation from the Snowy Mountains, Australia. Plant Ecol. 2018, 219, 209-216. [CrossRef]

59. Menzel, A.; Helm, R.; Zang, C. Patterns of late spring frost leaf damage and recovery in a European beech (Fagus sylvatica L.) stand in south-eastern Germany based on repeated digital photographs. Front. Plant Sci. 2015, 6, 110. [CrossRef]

60. Li, H.; Qiang, S.; Qian, Y. Physiological response of different croftonweed (Eupatorium adenophorum) populations to low temperature. Weed Sci. 2008, 56, 196-202. [CrossRef]

61. Mostofa, M.G.; Yoshida, N.; Fujita, M. Spermidine pretreatment enhances heat tolerance in rice seedlings through modulating antioxidative and glyoxalase systems. Plant Growth Regul. 2014, 73, 31-44. [CrossRef]

62. Dietrich, C.C.; Kreyling, J.; Jentsch, A.; Malyshev, A.V. Intraspecific variation in response to magnitude and frequency of freeze-thaw cycles in a temperate grass. Aob Plants. 2017, 10, 68. [CrossRef] [PubMed]

63. Hasani, Z.; Pirdashti, H.; Yaghoubian, Y.; Nouri, M.Z. Comparative effects of cold air and cold water stress on chlorophyll parameters in rice (Oryza sativa L.). IJFAS 2013, 21, 918-921.

64. Liu, X.G.; Xu, H.; Zhang, J.Y.; Liang, G.W.; Liu, Y.T.; Guo, A.G. Effect of low temperature on chlorophyll biosynthesis in albinism line of wheat (Triticum aestivum) FA85. Physiol. Plant. 2012, 145, 384-394. [CrossRef] [PubMed]

65. Aghaee, A.; Moradi, F.; Zare-Maivan, H.; Zarinkamar, F.; Irandoost, H.P.; Sharifi, P. Physiological responses of two rice (Oryza sativa L.) genotypes to chilling stress at seedling stage. Afr. J. Biotechnol. 2011, 10, 7617-7621.

66. Wang, Q.; Ding, T.; Gao, L.; Pang, J.; Yang, N. Effect of brassinolide on chilling injury of green bell pepper in storage. Sci. Hortic. 2012, 144, 195-200. [CrossRef]

67. Liu, Z.; Hu, H.; Yu, H.; Yang, X.; Yang, H.; Ruan, C.; Wang, Y.; Tang, J. Relationship between leaf physiologic traits and canopy color indices during the leaf expansion period in an oak forest. Ecosphere 2015, 6, 1-9. [CrossRef]

68. Hniličková, H.; Hejnák, V.; Nĕmcová, L.; Martinková, J.; Skalický, M.; Hnilička, F.; Grieu, P. The effect of freezing temperature on physiological traits in sunflower. Plant Soil Environ. 2017, 63, 375-380.

69. Wang, Z.; Cao, J.; Jiang, W. Changes in sugar metabolism caused by exogenous oxalic acid related to chilling tolerance of apricot fruit. Postharvest Biol. Tec. 2016, 114, 10-16. [CrossRef] 
70. Pospíšil, P.; Skotnica, J.; Nauš, J. Low and high temperature dependence of minimum $F_{\mathrm{o}}$ and maximum $F_{\mathrm{m}}$ chlorophyll fluorescence in vivo. Biochim. Biophys. Acta 1998, 1363, 95-99. [CrossRef]

71. Ishikawa, H.A. Ultrastructural features of chilling injury: Injured cells and the early events during chilling of suspension-cultured mung bean cells. Am. J. Bot. 1996, 83, 825-835. [CrossRef]

72. Lütz, C.; Bergweiler, P.; Di Piazza, L.; Holzinger, A. Cell organelle structure and function in Alpine and Polar plants are influenced by growth conditions and climate. In Plants in Alpine Regions; Lütz, C., Ed.; Springer: Vienna, Austria, 2012; pp. 43-60.

73. Naeem, M.S.; Warusawitharana, H.; Liu, H.; Liu, D.; Ahmad, R.; Waraich, E.A.; Xu, L.; Zhou, W. 5-Aminolevulinic acid alleviates the salinity-induced changes in Brassica napus as revealed by the ultrastructural study of chloroplast. Plant Physiol. Biochem. 2012, 57, 84-92. [CrossRef] [PubMed]

74. Lu, Y.; Hu, Y.; Snyder, R.L.; Kent, E.R. Tea leaf's microstructure and ultrastructure response to low temperature in indicating critical damage temperature. Inf. Process. Agric. 2019, 6, 247-254. [CrossRef]

75. Ristic, Z.; Ashworth, E.N. Changes in leaf ultrastructure and carbohydrates in Arabidopsis thaliana L. (Heyn) cv. Columbia during rapid cold acclimation. Protoplasma 1993, 172, 111-123. [CrossRef]

76. Babenko, L.M.; Kosakivska, I.V.; Akimov, Y.A.; Klymchuk, D.O.; Skaternya, T.D. Effect of temperature stresses on pigment content, lipoxygenase activity and cell ultrastructure of winter wheat seedlings. Genet. Plant Physiol. 2014, 4, 117-125.

77. Zhang, J.H.; Huang, W.D.; Liu, Y.P.; Pan, Q.H. Effects of temperature acclimation pretreatment on the ultrastructure of mesophyll cells in young grape plants (Vitis vinifera L. cv. Jingxiu) under cross-temperature stresses. J. Integr. Plant Biol. 2005, 47, 959-970. [CrossRef]

78. Nemoto, S.; Takeda, K.; Yu, Z.; Ferrans, V.J.; Finkel, T. Role for mitochondrial oxidants as regulators of cellular metabolism. Mol. Cell Biol. 2000, 20, 7311-7318. [CrossRef]

79. Xin, J.; Zhang, Y.; Tian, R. Tolerance mechanism of Triarrhena sacchariflora (Maxim.) Nakai. seedlings to lead and cadmium: Translocation, subcellular distribution, chemical forms and variations in leaf ultrastructure. Ecotox. Environ. Safe 2018, 165, 611-621. [CrossRef]

80. Giełwanowska, I.; Pastorczyk, M.; Kellmann-Sopyła, W.; Górniak, D.; Górecki, R.J. Morphological and ultrastructural changes of organelles in leaf mesophyll cells of the Arctic and Antarctic plants of Poaceae family under cold influence. Arct. Antarct. Alp. Res. 2015, 47, 17-25. [CrossRef] 